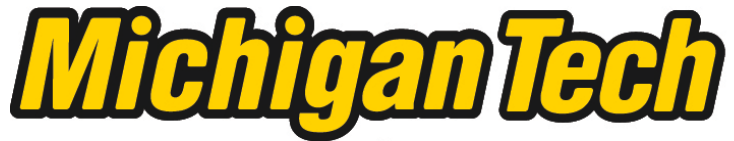 \\ Michigan Technological University Create the Future Digital Commons @ Michigan Tech
}

2012

\section{The long-term effects of whole-tree harvest at final felling on soil properties in a Norway Spruce (Picea Abies (L) Karst.) Stand}

Lilli M. Kaarakka

Michigan Technological University

Follow this and additional works at: https://digitalcommons.mtu.edu/etds

Part of the Forest Sciences Commons

Copyright 2012 Lilli M. Kaarakka

\section{Recommended Citation}

Kaarakka, Lilli M., "The long-term effects of whole-tree harvest at final felling on soil properties in a Norway Spruce (Picea Abies (L) Karst.) Stand", Master's Thesis, Michigan Technological University, 2012. https://doi.org/10.37099/mtu.dc.etds/166

Follow this and additional works at: https://digitalcommons.mtu.edu/etds

8 Part of the Forest Sciences Commons 


\title{
THE LONG-TERM EFFECTS OF WHOLE-TREE HARVEST AT FINAL FELLING ON SOIL PROPERTIES IN A NORWAY SPRUCE (PICEA ABIES (L) KARST.) STAND
}

\author{
By
}

Lilli M. Kaarakka

\begin{abstract}
A THESIS
Submitted in partial fulfillment of the requirements for the degree of MASTER OF SCIENCE In Forest Ecology and Management
\end{abstract}

MICHIGAN TECHNOLOGICAL UNIVERSITY 2012 (C) 2012 Lilli M. Kaarakka 
This thesis, "The Long-term Effects of Whole-tree Harvest at Final Felling on Soil Properties in a Norway spruce (Picea abies (L) Karst.) Stand," is hereby approved in partial fulfillment of the requirements for the Degree of MASTER OF SCIENCE IN FOREST ECOLOGY AND MANAGEMENT.

School of Forest Resources and Environmental Science

Signatures

Thesis Co-advisor

Dr. Andrew Burton

Thesis Co-advisor

Dr. Heljä-Sisko Helmisaari

Committee member

Dr. Casey Huckins

Committee member

Dr. Martin Jurgensen

Dean

Dr. Terry Sharik 


\section{Table of Contents}

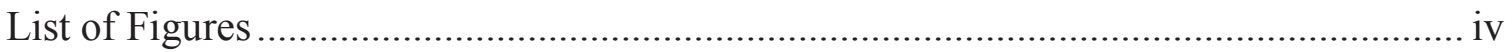

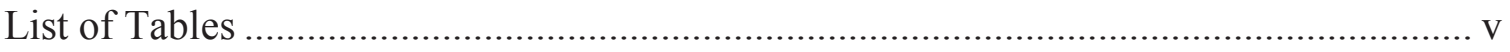

Acknowledgements............................................................................................ vii

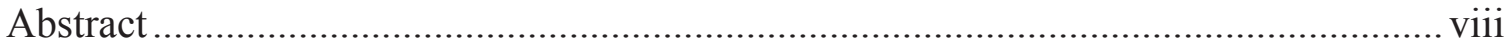

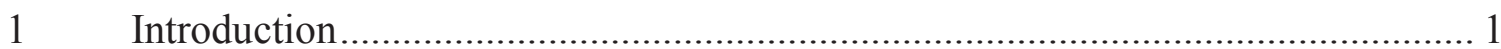

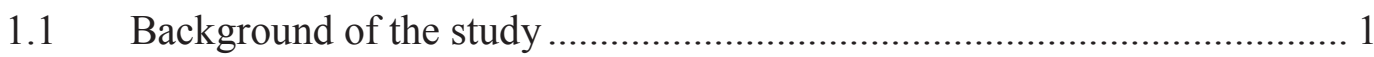

1.2 Objective of the study and hypothesis ...................................................... 3

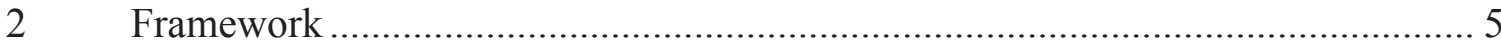

2.1 Forest nutrient cycling and soil productivity ............................................. 5

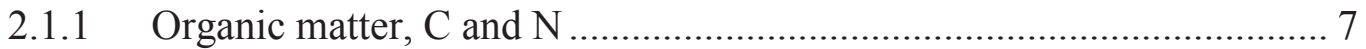

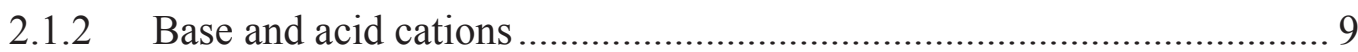

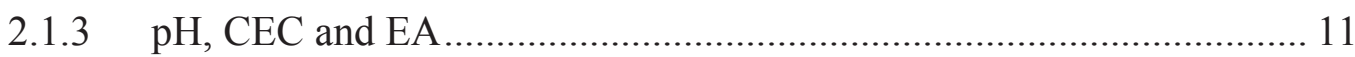

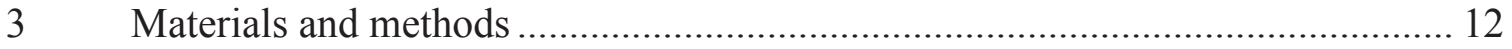

3.1 Study site and experimental design..................................................... 12

3.2 Soil sampling and analysis................................................................. 14

3.3 Soil chemical analysis ...................................................................... 15

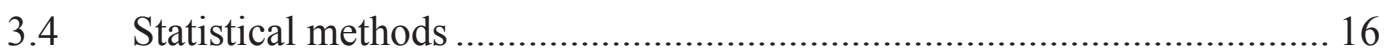

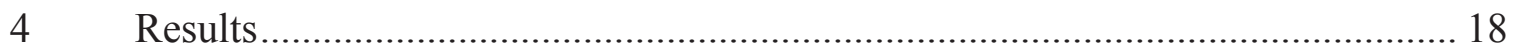

4.1 Total elemental pools ...................................................................... 18

4.2 Exchangeable nutrient pools ............................................................... 18

4.3 Soil acidity and cation exchange capacity .............................................. 19

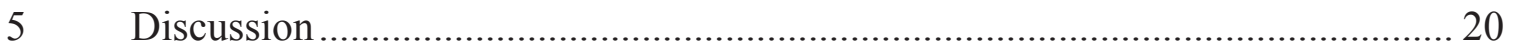

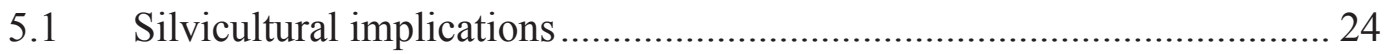

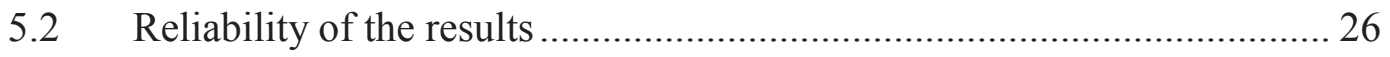

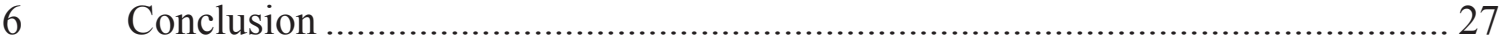

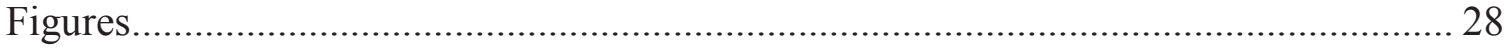

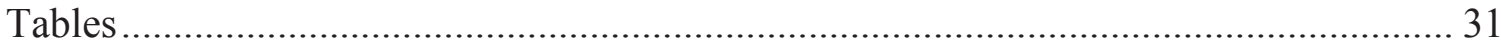

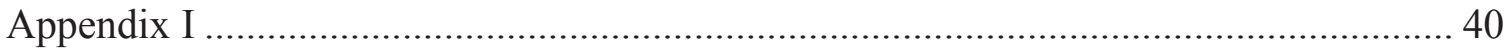

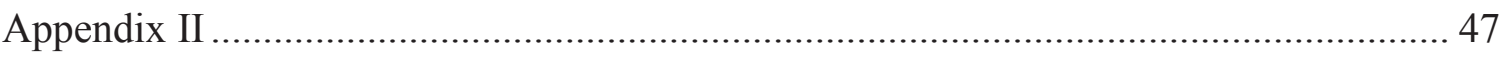

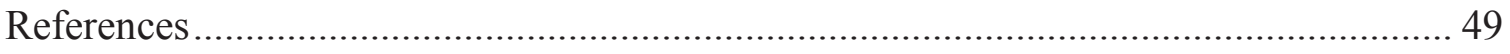

iii 


\section{List of Figures}

Figure 1 Competing vegetation was abundant in the experimental stand (Photo: L.

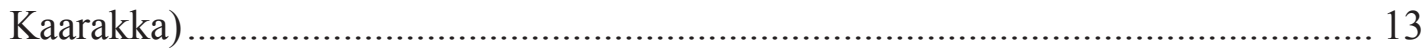

Figure 2 The soil-sampling pit (Photo: L. Kaarakka) ................................................. 14

Figure 3 Nutrient dynamics in a typical Norway spruce stand (Modified from Likens \&

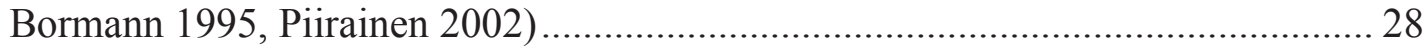

Figure 4 The site location in Janakkala, Southern Finland (Data source: National Land Survey of Finland-Appendix II includes the licence) ........................................ 29

Figure 5 The size of each plot is $30 \times 30 \mathrm{~m}$, surrounded by a five-meter buffer zone

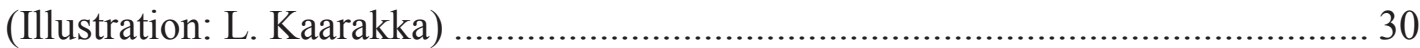




\section{List of Tables}

Table 1 Nitrogen $(\mathrm{N})$, potassium $(\mathrm{K})$ and calcium $(\mathrm{Ca})$ deposition, weathering, leaching and total and exchangeable pools in the organic layer and mineral soil in Finland (Starr et al. 1998, Ruoho-Airola et al. 2003, Piirainen et al. 2004, Palviainen 2005, Helmisaari et al. 2008, Palviainen and Finér 2012). Stars indicate missing data..... 31

Table 2 The experimental design of the thinning experiment (old) and final-felling

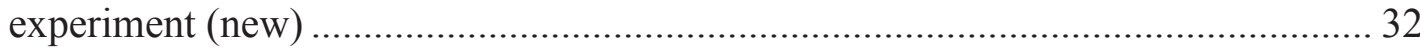

Table 3 The estimated mass of logging residue mass $\left(\mathrm{kg} \mathrm{ha}^{-1}\right)$ and nutrients contents $(\mathrm{kg}$ $\mathrm{ha}^{-1}$ ) removed or retained at the experimental site during thinnings (Helmisaari et al. 2011) 33

Table 4 Estimated mass $\left(\mathrm{kg} \mathrm{ha}^{-1}\right)$ and nutrient content of logging residues retained $(\mathrm{CH})$ and removed (WTH) from each plot at final felling (Hakkila et al. 1998).

Table 5 Humus thickness $(\mathrm{cm})$, bulk density of the mineral soil samples $\left(\mathrm{g} \mathrm{cm}^{-3}\right)$, particle size distribution of the fine-earth (\%), gravel content (\%) and stone content (\%) in the sampled plots 35

Table 6 Total elemental pools for carbon $\left(\mathrm{kg} \mathrm{ha}^{-1}, \mathrm{C}\right.$ in $\left.\mathrm{t} \mathrm{ha}^{-1}\right), \mathrm{C} / \mathrm{N}$-ratio and loss-on-

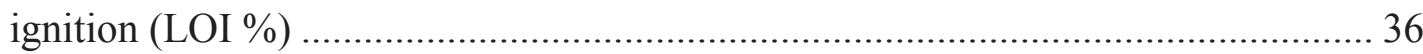

Table 7 Pools of exchangeable elements $\left(\mathrm{kg} \mathrm{ha}^{-1}\right)$ and base-acid-cation ratios................ 37

Table $8 \mathrm{pH}$, exchangeable acidity $\left(\mathrm{cmol}_{(+)} \mathrm{kg}^{-1}\right)$, effective cation exchange capacity

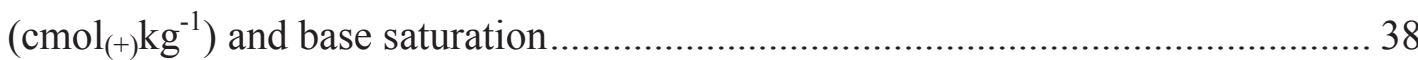

Table $9 \mathrm{C} / \mathrm{N}$-ratio and total elemental pools $\left(\mathrm{kg} \mathrm{ha}^{-1}, \mathrm{C}\right.$ in tha $\left.{ }^{-1}\right)$ of the organic layer in 1989 and 2011 with their relative difference 39

Table 10 One-way ANOVA for the treatment effect on total elemental pools in the organic layer.

Table 11 One-way ANOVA for the treatment effect on total elemental pools in the mineral soil

Table 12 One-way ANOVA for the treatment effect on exchangeable elemental pools in the organic layer. 
Table 13 One-way ANOVA for the treatment effect on exchangeable elemental pools in

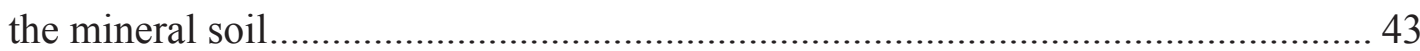

Table 14 One-way ANOVA for the treatment effect on cation rations in the organic layer

Table 15 One-way ANOVA for the treatment effect on cation rations in the mineral soil.

Table 16 One-way ANOVA for the treatment effect on the soil effective cation exchange capacity (ECEC), base saturation (BS \%) and exchangeable acidity (EA) ............. 45

Table 17 One-way ANOVA for the treatment effect on the soil $\mathrm{pH}$ and $\mathrm{H}^{+}$ion

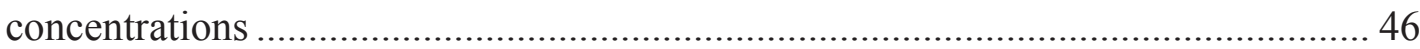




\section{Acknowledgements}

This thesis is part of a dual degree completed at Michigan Technological University and University of Helsinki, as part of the Transatlantic Master's Degree in Forest Resources. I would like to thank the Atlantis-program for making this study exchange possible.

My deepest gratitude goes to my advisors Dr. Heljä-Sisko Helmisaari at University of Helsinki and Dr. Andrew Burton at Michigan Technological University, whose advice and guidance made this thesis possible. In addition, I would like to thank Dr. Pekka Tamminen and Dr. Anna Saarsalmi at the Finnish Forest Research Institute for guidance and mentoring. I would also like to express my gratitude to my committee members Dr. Casey Huckins and Dr. Martin Jurgensen, who provided me with valuable feedback during the writing process. A big word of gratitude also goes to Marjut Wallner at University of Helsinki, who patiently advised me through the complex world of soil chemical analysis and laboratory work. I would also like to thank Finnish Forest Research Institute, Ecosystem Science Center and University of Helsinki for funding the project and the associated conference trips where the results have been presented.

I feel very privileged for having been accepted into the Atlantis-dual degree program and I would like to thank everyone involved in the program at University of Helsinki, Michigan Technological University and Swedish University of Agricultural Sciences. Specifically I would like to thank Maija Kovanen, Dr. Shekhar Joshi and Dr. Eric Agestam for coordinating this program.

On a personal note, I would like to express my deepest gratitude to my husband Hannu Aukia, who has supported me in all my decisions and travelled with me to the other side of the world. I would like to thank my family in Finland for all the words of encouragement and support. Finally, I am eternally grateful to all my friends around the world for being there for me. 


\begin{abstract}
Increased demand for forest-derived biomass has resulted in changes in harvest intensities in Finland. Conventional stem-only harvest $(\mathrm{CH})$ has to some extent been replaced with whole-tree harvest (WTH). The latter involves a greater removal of nutrients from the forest ecosystem, as all the above ground biomass is exported from the site. This has raised concerns that WTH could result in large changes in the nutrient dynamics of a forest stand and could eventually lower its site productivity. Little empirical data exists to support this assumption as only a limited number of studies have been conducted on the topic. A majority of these discuss the short-term effects, thus the long-term consequences remain unknown.
\end{abstract}

The objective of this study was to compare differences in soil properties after $\mathrm{CH}$ and WTH in a fertile Norway spruce (Picea abies (L) Karst.) stand in Southern Finland. The site was clear-felled in August 2000 and spruce seedlings were planted in the following summer. Soil sampling in the form of systematic randomized sampling was carried out in May 2011. Changes in base saturation, cation exchange capacity, elemental pools (total and exchangeable) and acidity were studied in both organic and mineral horizons. The results indicate that WTH lowered effective cation exchange capacity and base saturation particularly in the humus layer. The pools of exchangeable Al and Fe were increased in the humus layer, whereas the amount of exchangeable Ca decreased in both layers. WTH also resulted in lower $\mathrm{Ca} / \mathrm{Al}$-ratios across the sampled layers. Treatment did not have a significant effect on $\mathrm{pH}$, total pools of elements or on the $\mathrm{C} / \mathrm{N}$-ratio of the soil. The results suggest that although the stand possesses significant pools of nutrients at present, WTH, if continued, could have long-term effects on site productivity. 


\section{Introduction}

\subsection{Background of the study}

Developing strategies to prevent climate change are both national and international interests of the European Union member states (European Commission 2008). Reducing the dependency on non-renewable energy sources and decreasing carbon emissions from fossil fuel combustion are among the goals of current European climate policy (European Commission 2008, Walmsley et al. 2009, Vanguelova et al. 2010). Particularly in the forested regions of Europe, utilization of forest-derived biomass is viewed as a tool to combat climate change and simultaneously improve national energy security (Stupak et al. 2007).

Productive forests cover two thirds of Finland's land area (Ylitalo 2011). The consumption of roundwood per capita is high $\left(15 \mathrm{~m}^{3}\right.$ per capita), and as a result forest biomass (logging residue/slash) is readily available with a relatively low cost (Hakkila and Parikka 2002, Ericsson 2004, Hakkila 2006). Even-aged forest management predominates in Finnish forestry, with annual clear-cuts covering approximately $1-2 \%$ of the total forest area (Palviainen 2005). Scots pine (Pinus sylvestris), Norway spruce (Picea abies) and birch (Betula sp.) are the dominant tree species in Finland, with pine and spruce representing $80 \%$ of the standing stock (volume) (Ylitalo 2011).

The Nordic countries have a long tradition of utilizing their forest resources intensively for both industry and energy purposes (Ericsson 2004), and the use of forest-derived biomass for energy has steadily increased in the region during the past 15 years (Björheden 2006, Ylitalo 2011, Egnell 2011). As a European Union member country Finland aims to reduce GHG emissions by $20 \%$ and increase the use of renewable energy sources by $20 \%$ before 2020 (European Commission 2008). The Finnish government has set an ambitious target of doubling the use of forest chips from current 6.2 million $\mathrm{m}^{3}$ to 13.5 million $\mathrm{m}^{3}$ by the year 2020 to meet the EU targets (Laitila et al. 2008, Ylitalo 
2011). In practice, this would mean that logging residues (topwood, foliage and branches) should be collected from nearly all the clear-cut sites (Luiro et al. 2010).

Due to these targets, whole-tree harvest (WTH) in which all above ground biomass is removed from site after logging is becoming an alternative to conventional harvest $(\mathrm{CH})$ in parts of Fennoscandinavia (Proe and Dutch 1994, Jacobson et al. 2000). Use of WTH involves a greater removal of nutrients from the forest ecosystem as all the aboveground biomass is exported from the site (Likens et al. 1970, Worrell and Hampson 1997, Hakkila and Parikka 2002). This has raised concerns that WTH could change the nutrient dynamics of a forest stand and eventually lowers its site productivity (e.g. Mälkönen 1976, Kimmins 1977, Burger 2002, Helmisaari et al. 2008). Fairly little empirical data exists to support this assumption as only a limited number of studies have been conducted on the topic. A majority of these discuss the short-term effects, thus the long-term consequences remain to some extent unknown. Many of the previous WTH studies have focused on relatively nutrient poor-sites and how these sites respond to WTH in terms of seedling nutrient status (Proe and Dutch 1994, Bélanger et al. 2003, Thiffault et al. 2006, Saarsalmi et al. 2010). Furthermore, past Norway spruce WTH experiments in Fennoscandinavia have been associated with relatively weathered, podzolic soils (moderately mesic), rather than fertile, fine-textured soils (mesic) (Olsson et al. 1996b, Wall and Hytönen 2011).

Logging residues represent a significant pool of the nutrients in a commercial forest stand in Finland (Finér et al. 2003, Palviainen et al. 2004b). In WTH more biomass is harvested at once, as approximately $70 \%$ of the residue is removed (Laitila et al. 2008), causing the nutrient removals to double or triple compared with CH (Kimmins 1977, Walmsley et al. 2009, Palviainen and Finér 2012). Stand developmental stage determines the allocation of biomass; the proportion of nutrient-rich foliage and bark decreases with stand age (i.e. nutrient demand vs. timing of harvest) (Mälkönen 1976, Augusto et al. 2000, Helmisaari et al. 2009, Helmisaari et al. 2011). According to Mälkönen (1976) a Norway spruce crown contains approximately $30 \%$ of the total dry mass but more than $65 \%$ of the total 
nutrients at the thinning-stage, halfway through rotation, making the removal of logging residue disproportionate to the nutrient demand of the stand. In fact, the nutrient demand is highest in young stands before canopy closure (Mahendrappa et al. 1986, Jacobson et al. 2000, Prescott 2002, Smolander et al. 2008, Helmisaari et al. 2011, Palviainen and Finér 2012). Thus thinning aged stands could be more sensitive to logging residue removal than mature stands. There is evidence that WTH can cause growth reductions in thinnings (Jacobson et al. 2000, Helmisaari et al. 2011) but studies have not shown any effects on nutrient status of the remaining trees (Luiro et al. 2010). Nutrient concentrations and biomass production also differ between tree species; Norway spruce typically allocates a large proportion of the biomass to its crown (Finér et al. 2003, Repola 2009).

A number of studies conducted in the boreal region have demonstrated that WTH could result in growth losses in both thinnings (Jacobson et al. 2000, Helmisaari et al. 2011) and final harvest (Proe and Dutch 1994, Walmsley et al. 2009, Wall and Hytönen 2011, Egnell 2011). It has also been reported that WTH can have an impact on nutrient pools and acidity (Mälkönen 1976, Olsson et al. 1996a, Olsson et al. 1996b, Olsson et al. 2000, Helmisaari et al. 2002, Thiffault et al. 2006, Smolander et al. 2008, Vanguelova et al. 2010, Smolander et al. 2010, Tamminen et al. 2012), leaching of Ca and N (Likens et al. 1970, Rosen and Lundmark-Thelin 1987, Wall 2008) and the growth of the subsequent tree generation (Egnell and Leijon 1999, Olsson et al. 2000, Thiffault et al. 2006).

In a recent review Thiffault et al. (2011) concluded that there are no universal and consistent effects of WTH on soil productivity. Several other studies also have indicated that site sensitivity to WTH can vary across gradients in climate and elevation, amongst other things (Olsson et al. 1996b, Thiffault et al. 2006, Wall and Hytönen 2011).

\subsection{Objective of the study and hypothesis}

The objective of this study was to compare the differences in soil properties after $\mathrm{CH}$ and WTH in a fertile Norway spruce (Picea abies) stand, 10-years after a clear-cut. In WTH, 
all the aboveground biomass including tops, branches and needles were exported from the harvest site. In $\mathrm{CH}$, only the merchantable stem was removed from logging site. In contrast to $\mathrm{CH}$, WTH involves a relatively large removal of nutrients from the stand.

It is hypothesized that WTH could result in nutrient depletion thus impairing site productivity, particularly on nutrient-poor sites.

Certain soil properties were chosen as indicators of the change within the organic and mineral soil layer:

1. $\mathrm{C} / \mathrm{N}$-ratio and pools of $\mathrm{C}$ and $\mathrm{N}\left(\mathrm{kg} \mathrm{ha}^{-1}\right)$

2. Exchangeable and total elemental pools of cations: $\mathrm{Ca}, \mathrm{Mg}, \mathrm{K}, \mathrm{Al}$ and $\mathrm{Fe}(\mathrm{kg}$ $\mathrm{ha}^{-1}$ )

3. Cation exchange capacity $\left(\mathrm{cmol}_{(+)} \mathrm{kg}^{-1}\right)$ and base saturation (\%)

4. $\mathrm{pH}$ and exchangeable acidity $\left(\mathrm{cmol}_{(+)} \mathrm{kg}^{-1}\right)$

Hypothesis

WTH on fertile, fine-textured soil has no effect on any of the above soil properties in the organic layer or in the mineral soil

The site is a relatively fertile (OMT-type) and abundant with grasses and herbs (mesic). This implies that the soil could possess sufficient buffering capacity to resist change of $\mathrm{pH}$ and acidification after WTH. On the other hand, the abundance of competing vegetation and thus litterfall could also "mask" the different treatment effects (Wall 2008, Tamminen et al. 2012). 


\section{Framework}

\subsection{Forest nutrient cycling and soil productivity}

According to Burger (2002) "forest soil productivity is the capacity of a soil to contribute to forest biomass production". Thus in a forested ecosystem, soil productivity can be estimated by measuring net primary production of a given area per unit of time (Mahendrappa et al. 1986, Burger 2002). Compartments (vegetation, soil, atmosphere) of an ecosystem interact with each other by exchanging elements, such as nutrients (Likens and Bormann 1995, Piirainen 2002, Piirainen et al. 2007). Over time the rate of the exchange varies and these nutrient pools may either increase or decrease in each compartment (Piirainen 2002, Brady and Weil 2008). Forested ecosystems, particularly conifer-dominated ones, are efficient in recycling, conserving and storing elements (Brady and Weil 2008). Trees take up carbon directly from the atmosphere whereas the other elements enter the system through atmospheric deposition and weathering of the parent material (Likens and Bormann 1995, Piirainen 2002, Brady and Weil 2008). Forestry operations change the timing and quantity of these fluxes (Palviainen 2005).

In an undisturbed forest system the largest flux of organic matter and nutrients to the soil comes from litterfall (Likens and Bormann 1995, Piirainen 2002, Saarsalmi et al. 2007) and the nutrients returning to the forest floor are effectively recycled within the system (Figure 3) (Likens and Bormann 1995, Prescott 2002, Ukonmaanaho et al. 2008, Brady and Weil 2008). The quantity and timing of litterfall varies according to season and tree species (Ukonmaanaho et al. 2008), with the production being closely linked to the basal area of the forest (Mahendrappa et al. 1986).

Most forest management practices cause physical disturbance to the soil and the forest floor (Johnson et al. 1991b, Hope 2007, Brady and Weil 2008). The intensity of the harvest operation determines the extent of the disturbance (Jurgensen et al. 1997). In 
Finland clear-cutting in combination with site preparation is the predominant method used at final felling (Ylitalo 2011). Stands are logged with a harvester, which piles the logging residues next to the skit trails. In the WTH, the residue is transported from the stand by a forwarder (Nurmi 2007). Stands suited for Norway spruce are typically mounded and planted with two- or three-year-old seedlings after the harvest, prior to the next growing season (Hallsby and Örlander 2004). Site preparation can improve seedling survival on wet and fertile sites with competitive grasses and herbs. It has been reported that removal of logging residues could facilitate the establishment of the next tree generation, as planting and soil preparation are both is easier (Proe and Dutch 1994, Saksa et al. 2002).

From a stand point-of-view, clear-cuts are sudden disturbances that significantly affect C, N and nutrient pools (Mälkönen 1976, Finér et al. 2003, Palviainen 2005, Piirainen et al. 2007). In a conventional clear-cut, large quantities of biomass are left on site in the form of logging residue thus creating a peak in the nutrient flux to the soil and the forest floor (Likens et al. 1970, Olsson et al. 1996b, Palviainen 2005). Furthermore, harvesting equipment can cause soil compaction, redistribution of the forest floor organic matter and vertical dislocation of soil organic matter (Johnson et al. 1991b, Prescott et al. 2000, Burger 2002). The mixing of the organic humus layer and mineral soil in turn promotes mineralization and decomposition processes (Prescott et al. 2000).

According to Nurmi (2007), conventional harvest combined with logging residue extraction removes $60-80 \%$ of the dry residue mass. This amount corresponds to the estimates of potential logging residues removals associated with whole-tree harvest on Norway spruce clear-cuts (Laitila et al. 2008, Peltola et al. 2011). Norway spruce allocates a large proportion of biomass to its crown and particularly to the foliage (Repola 2009); the proportion of logging residues of the total aboveground biomass is about $30 \%$ (Hakkila et al. 1998). Logging residue is therefore readily available on spruce logging sites and used as a "protective mat" on skid trails (Smolander et al. 2010, Saarsalmi et al. 2010). 


\subsubsection{Organic matter, $\mathrm{C}$ and $\mathrm{N}$}

Soil organic matter (SOM) is considered the most important indicator of soil quality (e.g. (Doran and Jones 1996, Brady and Weil 2008). It serves as a sink and source of nutrients as well as a natural buffer against erosion and leaching. Furthermore, SOM provides much of soil's cation exchange capacity. In a boreal forest stand organic matter accumulates on the soil surface forming humus (Prescott et al. 2000) and this matter is incorporated into the surface layers of the soil. The extent to which clear-cuts affect SOM depends on several factors: (1) the intensity of the treatment, (2) the quantity of forest floor removed and (3) amount of organic matter on the soil surface, i.e. the thickness and quality of the organic layer (Jurgensen et al. 1997, Prescott et al. 2000, Burger 2002). Clear-cuts remove large quantities of organic matter from a forest stand thus it would seem inevitable that WTH could results in lower OM content in the surface layers of the soil. The results from previous WTH studies on soil organic matter and C pools have been somewhat ambiguous. In a meta-analysis Johnson and Curtis (2001), concluded that forest harvest in general has little or no effect on soil $\mathrm{C}$ and $\mathrm{N}$ pools. However, they also suggest that WTH results on average in a $6 \%$ decrease in the soil $\mathrm{C}$ and $\mathrm{N}$ in coniferous species (Johnson and Curtis 2001). Short-term studies conducted in Finland and United States have found no evidence that WTH reduces soil organic matter pools, $\mathrm{C}$ or $\mathrm{N}$ (Johnson et al. 1991b, Wall 2008). Smolander et al. (2008) reported lower C mineralization rates in a fertile Norway spruce stand 10 years after WTH thinning in Eastern Finland. In Sweden, Olsson et al. (1996b) reported a 17\% net reduction in the total C pool for fertile Norway spruce sites after clear-felling, but this reduction was not dependent on the harvest intensity per se. Several other long-term studies have not shown significant effects of WTH on total soil C in connection with final felling (Johnson et al. 2002, Thiffault et al. 2006, Vanguelova et al. 2010). There have been reports that $\mathrm{CH}$ reduces $\mathrm{C}$ and $\mathrm{N}$ pools more than $\mathrm{WTH}$, thus implying that retention of logging residues could actually increase the rate of mineralization of the existing soil organic matter stocks (Moroni et al. 2007, Vanguelova et al. 2010). Similarly, Rosen and Thelin (1987) found that retention of logging residues could result in increased leaching of inorganic $\mathrm{N}$ after a 
clear-cut. In Finland, Saarsalmi et al. (2010) reported significantly lower C, N and Ca pools as result of WTH at final felling in a Scots pine stand.

Logging residues represent a large reservoir of $\mathrm{C}$ and nutrients within the forest stand (Palviainen et al. 2004b). Studies in the Nordic countries have shown that logging residue decomposition rate decreases with increasing substrate diameter (Fahey et al. 1991, Hyvönen et al. 2000) and it also correlates with site productivity (Johansson 1994). Palviainen et al. (2004) reported $40 \%$ mass loss for green spruce needles and $20 \%$ loss for braches three years after a clear-cut. Almost a half of C (42\%) in the green needles was lost within the same time frame whereas the $\mathrm{C}$ loss from branches was more subtle (20\%) implying that the latter could serve as a longer term source of organic matter of nutrient release (Fahey et al. 1991, Hyvönen et al. 2000, Palviainen et al. 2004b).

In the boreal region, $\mathrm{N}$ is considered the principal nutrient limiting forest growth (e.g. Mälkönen 1976, Kimmins 1977, Bonan and Shugart 1989, Burger 2002), and N is strongly recycled within the system (Likens et al. 1970, Piirainen et al. 2002, Palviainen et al. 2004b). Anthropogenic N deposition has gradually increased in Fennoscandinavia during the last several decades (Sverdrup and Rosen 1998, Akselsson et al. 2007). However, $\mathrm{N}$ deposition tends to decrease with higher latitudes, thus the annual $\mathrm{N}$ deposition in Finland is remains fairly low: $2-6 \mathrm{~kg}$ per ha (Helmisaari et al. 2008) (Table 1). The nitrogen cycle is closely linked to that of organic matter i.e. carbon. The $\mathrm{C} / \mathrm{N}$ ratio of the logging residue largely determines whether $\mathrm{N}$ is mineralized or immobilized within the system (Brady and Weil 2008). High $\mathrm{C} / \mathrm{N}$ will slow decomposition and promote immobilization thus reducing the risk of leaching. Norway spruce needle litter typically has a relatively high C/N-ratio (70-75) (Smolander et al. 1996). In Norway spruce $80 \%$ of the total $\mathrm{N}$ is in needles, twigs and branches (Finér et al. 2003), out of which $70 \%$ is in the green needles (Helmisaari et al. 2009).

Logging effects on N can be delayed (Fahey et al. 1991, Hazlett et al. 2007) and studies on logging residue decomposition have suggested that in contrast to $\mathrm{C}$, there is no net 
release of $\mathrm{N}$ within the first years after a clear-cut (Hyvönen et al. 2000, Palviainen et al. 2004b). Helmisaari et al. (2011) argue that logging residues are a slow-release fertilizer in nutrient limited areas and they concluded, "Conclusions based on site productivity should be based on long-term sampling". In contrast, Wall (2008) argues that, in the short-term, removal of logging residue does not impair the soil $\mathrm{N}$ pool and the removal of logging residue decreases the risk of leaching. Jacobson et al. (2000) concluded, based on experimental data across Fennoscandinavia that the possible growth reduction after WTH thinning could be the result of reduced $\mathrm{N}$ supply. However, they also contemplated whether the growth reduction could be a result of an indirect effect such as changes in the microclimate or ground vegetation competition (Jacobson et al. 2000). Fahey et al. (1991) suggested that the ground vegetation could act a sink for nutrients after WTH, thus increasing competition for the nutrients. However, studies conducted in Sweden have not found any effect of harvest intensity on ground vegetation abundance and cover (Olsson and Staaf 1995, Rosenberg and Jacobson 2004) thus the quantitative role of vegetation as a sink of nutrients remains unclear (Hyvönen et al. 2000).

\subsubsection{Base and acid cations}

Weathering is the major source of calcium $(\mathrm{Ca})$, potassium $(\mathrm{K})$ and magnesium $(\mathrm{Mg})$ in boreal soils (Likens and Bormann 1995, Starr et al. 1998, Palviainen et al. 2012) particularly in areas with low atmospheric deposition such as the Nordic countries (Ruoho-Airola et al. 2003) (Table 1). Ca and Mg are relatively abundant in forest soils, both as structural components of minerals and in soluble, cation (i.e. plant-available) form (Likens and Bormann 1995, Brady and Weil 2008). Only a small fraction is bound to the vegetation (Likens and Bormann 1995). Litterfall accounts for a large amount of $\mathrm{Ca}$ and $\mathrm{Mg}$, and both are relatively immobile nutrients (Piirainen 2002). In contrast, potassium $(\mathrm{K})$ is not incorporated into any structures within the soil complex but instead remains in ionic form in the plant material thus making it a mobile nutrient (Olsson et al. 1996a, Brady and Weil 2008). After a clear-cut K, is released relatively rapidly from the

decomposing residue (Fahey et al. 1991, Palviainen et al. 2004a). Apart from providing 
vital nutrients for plants, base cations also act as neutralizers in soils that are naturally prone to acidify (Starr et al. 1998). It has been suggested that calcium could enhance decomposition processes through promoting presence of lignin-decaying fungi (Johansson 1994).

Aluminum ( $\mathrm{Al}$ ) is an abundant element in most soils however it's not a mineral nutrient (Giesler et al. 2000). Al and Fe cations are considered acid-forming cations as they can act as hydrolyzing agents within the soil, causing the release $\mathrm{H}^{+}$ions into the soil solution (Brady and Weil 2008). Studies in Finland have shown that Al and Fe are abundant in the rooting zone; as a result fine roots have high concentrations of both elements compared to other plant compartments (Domisch et al. 1998, Palviainen et al. 2004a).

Logging residue and particularly green needles have high nutrient concentrations (Olsson et al. 1996a, Helmisaari et al. 2008) and after the final-harvest the nutrients are released at different rates from different residue components (Palviainen 2005). $\mathrm{K}$ and $\mathrm{Ca}$ originate largely from the foliage, whereas $\mathrm{Al}$ and $\mathrm{Fe}$ from the fine roots (Palviainen et al. 2004a). Furthermore, almost all $\mathrm{K}, \mathrm{Al}$ and $\mathrm{Fe}$ are released primarily from the logging residue during the first years, whereas Ca releases relatively slowly over time (Olsson et al. 1996a, Palviainen et al. 2004a). Several studies have shown that WTH negatively affects base cation pools (Nykvist and Rosen 1985, Johnson et al. 1991a, Olsson et al. 1996a, Rosenberg and Jacobson 2004, Thiffault et al. 2006, Vanguelova et al. 2010). Swedish studies have reported negative balances for base cations after WTH, indicating that there could be a risk of soil base cation depletion after only one rotation (Sverdrup and Rosen 1998, Jacobson et al. 2000). In Finland, the upland mineral soils are N-limited (Finér et al. 2003) whereas organic, peat soils are often limited by the supply of $\mathrm{P}$ (Palviainen and Finér 2012). P is rapidly released from the logging residue after a clearcut (Palviainen et al. 2004b) but it is effectively retained in the mineral soil as a part of metal-organic-acid-complexes (Piirainen et al. 2004). The exchangeable P pool however was not quantified in this study. 


\subsection{3 pH, CEC and EA}

Trees attain nutrients through exchange with the soil solution: as base cations are assimilated into the biomass an equivalent sum of $\mathrm{H}^{+}$ions is released from the roots (Olsson et al. 1996a). Organic matter tends to acidify soil through decomposition, which releases $\mathrm{H}^{+}$ions into the soil complex and facilitates the leaching of $\mathrm{Ca}$ and $\mathrm{Mg}$ (Brady and Weil 2008). During harvest the nutrients are removed from the site in the form of biomass and decomposition of residual organic matter tends to increase, thus forest harvesting in general tends to be an acidifying practice (Kimmins 1977, Olsson et al. 1996a, Burger 2002). Numerous studies have not shown any effect of WTH on pH after final felling (Johnson et al. 1991a, Olsson et al. 1996a, Bélanger et al. 2003, Rosenberg and Jacobson 2004, Thiffault et al. 2006, Wall 2008, Walmsley et al. 2009, Saarsalmi et al. 2010). However, Nykvist and Rosen (1985) did observe a lower $\mathrm{pH}$ and decrease in base saturation after WTH. Correspondingly, also Vanguelova et al. (2010) measured a lower $\mathrm{pH}$ in the organic layer and mineral soil after WTH.

WTH has been reported to result in lower cation exchange capacity (CEC), higher exchangeable acidity (EA) and decreased base saturation (BS) in the soil profile (Johnson et al. 1991a, Olsson et al. 1996a, Bélanger et al. 2003, Thiffault et al. 2006). Changes in the $\mathrm{pH}$ are reflected to the proportional saturation of exchange capacity with acid and base cations. The exchange sites in the organic layer are predominantly $\mathrm{pH}$-dependent, thus making this layer more sensitive to changes in $\mathrm{pH}$ in comparison to mineral soil, which has higher proportion of permanent charge sites (Brady and Weil 2008). 


\section{Materials and methods}

\subsection{Study site and experimental design}

The experimental site utilized for this study was established by the Finnish Forest Research Institute as a part of a trial examining the long-term effects of whole-tree harvest on tree growth and soil properties. The original experiment was established in 1978 as the stand had reached thinning age (57 yrs.), and utilized a randomized block design with six different treatments (Table 2). The stand was thinned either conventionally or with whole-trees removed in 1979 and 1989 (Table 3). The experimental plots were assigned for the new treatment (i.e. final-felling) based on the old treatments. The stand is located in Janakkala, Southern Finland $\left(61.02^{\circ} \mathrm{N}\right.$, long. $24.69^{\circ} \mathrm{E}$ ) (Figure 4). The elevation of the site is $160 \mathrm{~m}$ with an annual precipitation of $616 \mathrm{~mm}$ and average temperature of $5.5{ }^{\circ} \mathrm{C}$ (temperature sum $1214^{\circ} \mathrm{C}$ ). The site is relatively fertile and herb-rich, thus classified as a mesic Oxalis acetocella-Vaccinium myrtillus (OMT) site type, (Cajander 1949). Competing vegetation, mainly trees and shrubs, such as Rowan (Sorbus aucuparia) and willows (Salix sp.) were abundant at the experimental site (Figure 1).

In August 2000, the experimental stand was clear-cut either conventionally $(\mathrm{CH})$ or completely (WTH-all above ground biomass) with a harvester. After stem-harvesting logging residues were distributed evenly on the $\mathrm{CH}$ plots. From the WTH plots, all the logging residues were removed during the harvest. The estimated mass of the harvested logging residues ranged from 32,000-53,000 kg ha-1 (Table 4). Norway spruce (Picea abies (L) Karst.) seedlings were planted in spring 2001 after light mounding. The experimental design for this study was a randomized block design and the two treatments $(\mathrm{CH}$ and $\mathrm{WTH})$ were organized into two blocks $(\mathrm{n}=9)$. The $30 \mathrm{~m}$ x $30 \mathrm{~m}(0.09 \mathrm{ha})$ plots were surrounded by a $5 \mathrm{~m}$ buffer zone (Figure 5 ). 

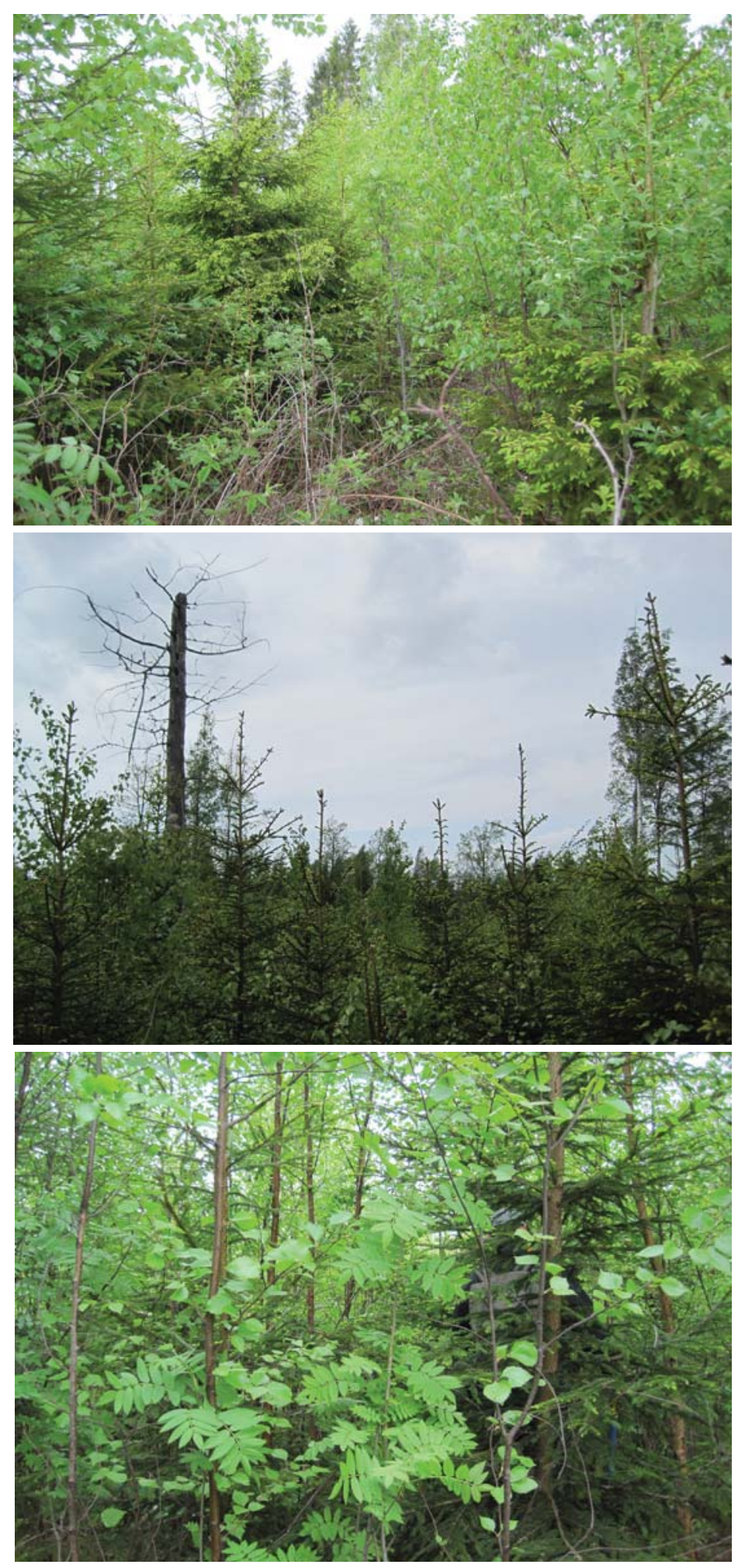

Figure 1 Competing vegetation was abundant in the experimental stand (Photo: L. Kaarakka) 


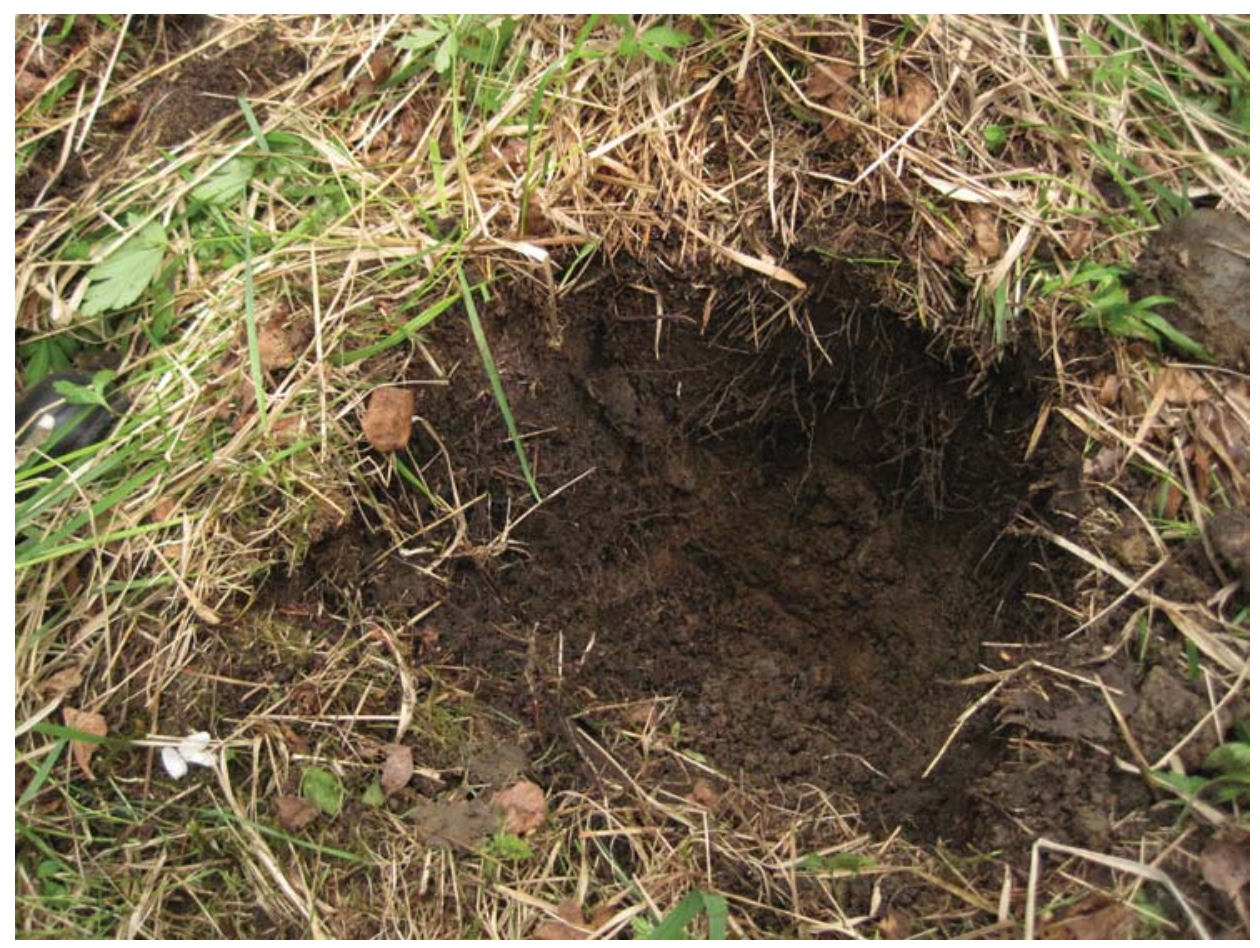

Figure 2 The soil-sampling pit (Photo: L. Kaarakka)

\subsection{Soil sampling and analysis}

Soil sampling was carried out in in May 2011 ten years after the final felling. One composite sample consisting of 25 subsamples was taken systematically from the organic layer $\left(\mathrm{O}_{\mathrm{fh}}\right)$ from each plot with a steel cylinder $(\mathrm{d}=60 \mathrm{~mm})$. The thickness and class of the humus was measured before the subsamples were combined. Similarly, nine subsamples of mineral soil $(0-10 \mathrm{~cm})$ were collected systematically with a steel cylinder $(d=39 \mathrm{~mm})$ from the plots. Subsamples were collected from undisturbed areas i.e. wheel tracks were avoided. One sample was collected from the mineral soil $(10-30 \mathrm{~cm})$ at the center of each plot for particle size analysis. Stone content was determined with a steel rod (Viro 1952). Two soil types were identified for the site: Haplic Cambisol and Haplic Regosol (Michéli et al. 2006, Tamminen 2009). The soil had a dark-brownish color, indicating high organic matter content (Figure 2). 


\subsection{Soil chemical analysis}

The soil samples were dried at $40{ }^{\circ} \mathrm{C}$ for five days after which larger soil aggregates were manually crushed and the samples further dried for seven days. Roots were manually removed from the fresh samples before drying. The mineral soil samples were sieved through a $2 \mathrm{~mm}$ screen and the organic samples milled with a $2 \mathrm{~mm}$ bottom-sieve. Losson-ignition and moisture content were determined after drying the samples at $105{ }^{\circ} \mathrm{C}$, overnight and, at $550{ }^{\circ} \mathrm{C}$ for two hours, respectively. Total $\mathrm{C}$ and $\mathrm{N}$ concentrations and $\mathrm{C} / \mathrm{N}$ ratios were determined directly from the homogenized soil samples with a VarioMax-analyzer. Soil $\mathrm{pH}_{(\mathrm{H} 20)}$ was measured with a glass electrode on suspensions of soil in demineralized water with a ratio of $20 \mathrm{ml}$ sample to $50 \mathrm{ml}$ of water, prior to which the samples had been shaken. To determine soil cation exchange capacity and exchangeable acidity, all the samples were extracted with a $0.1 \mathrm{M}$ barium chloride solution with a ratio of $10 \mathrm{ml}$ sample to $100 \mathrm{ml}$ of $\mathrm{BaCl}$. The samples were left over night, then shaken for two hours and finally filtered using Whatman-filter paper. The concentrations of exchangeable cations, $\mathrm{K}^{+}, \mathrm{Ca}^{2+}, \mathrm{Mg}^{2+}, \mathrm{Fe}^{3+}$ and $\mathrm{Na}^{+}$, in the $\mathrm{BaCl}$ extractions were determined by ICP-OES. Exchangeable acidity was determined by titrating an aliquot $(50 \mathrm{ml})$ with $0.1 \mathrm{M} \mathrm{NaOH}$ solution to $\mathrm{pH} 7$.

For determining total elemental concentrations one gram of mineral soil and approximately 300-500 milligrams of organic soil per sample were digested with $10 \mathrm{ml}$ of $\mathrm{HNO}_{3}$ and $1 \mathrm{ml}$ of $\mathrm{H}_{2} \mathrm{O}_{2}$. The samples were then heated in a microwave (Atomic absorption spectroscopy) at $175{ }^{\circ} \mathrm{C}$ and cooled after which the digestates were filtered with Whatman-filter paper, and stored in a cooler. Finally, total elemental concentrations were determined with the ICP-OES. Mineral soil samples from the deeper horizons were analyzed for particle size distribution with the Coulter LS230 laser-diffraction (LS) device.

Total and exchangeable pools of elements for the organic layer were calculated with the following equation (Tamminen and Starr 1994): 
Pool, $\mathrm{kg} \mathrm{ha}^{-1}=\frac{M * \text { concentration of element }\left(\mathrm{mg} \mathrm{g}^{-1}\right)}{1000}$

where: $\mathrm{M}$ is the mass of the humus-layer:

$\mathrm{M} \mathrm{kg} \mathrm{ha}^{-1}=\frac{100000 * \text { dry weight }(\mathrm{g})}{n: \text { o of subsamples } * \text { Cross section of cylinder }(\text { sampler }) \mathrm{cm}^{2}}$

Total and exchangeable pools of elements for the mineral layer were calculated with the following equation:

Pool, $\mathrm{kg} \mathrm{ha}^{-1}=m g \mathrm{~g}^{-1}\left(\mathrm{or} \mathrm{g} \mathrm{kg}^{-1}\right) * B D_{<2} g \mathrm{~cm}^{3} *$ thickness of horizon $\mathrm{cm} *(1-$ stone content $\% / 100) *$ unit conversion factor

Stone content was taken into account when estimating the total pools with the following empirical equation (Viro 1952):

Stone volume $\%=83-2.75 *$ average dent $\mathrm{cm}$

Effective cation exchange capacity (ECEC) was defined as the sum of exchangeable cations $\left(\mathrm{Ca}^{2+}+\mathrm{Mg}^{2+}+\mathrm{K}^{+}+\mathrm{Na}^{+}+\mathrm{Al}^{3+}+\mathrm{H}^{+}\right)$. Exchangeable $\mathrm{Fe}^{2+}$ was not included in the calculation of ECEC, as fairly little $\mathrm{Fe}^{2+}$ is retained in the cation exchange capacity. Base saturation (BS) was calculated as the fraction of ECEC occupied by base cations $\left(\mathrm{Ca}^{2+}+\mathrm{Mg}^{2+}+\mathrm{K}^{+}+\mathrm{Na}^{+}\right)$. Exchangeable acidity (EA) was measured from the $\mathrm{BaCl}$ extracted the samples by titrating to $\mathrm{pH}$ 7.0. The $\mathrm{pH}$ readings were converted into concentration of free $\mathrm{H}^{+}$ions per mass of soil.

\subsection{Statistical methods}

Means of the sampling points in each plot were used for all analyses. ANOVA (Analysis of variance) was used to test the effects of treatment on the selected soil properties. Residuals from ANOVA were tested for normality with Shapiro-Wilk test for all dependent variables and equality of variances were tested with Levene's test. Data for

plots $17(\mathrm{CH})$ and $18(\mathrm{WTH})$ were removed from total pool analysis for $\mathrm{Ca}, \mathrm{K}, \mathrm{Mg}$ and $\mathrm{P}$ due to extreme values (outliers, sample contamination in the microwave). All statistical 
analyses were completed with the SPSS statistical package Version 20 (IBM 2012). Detailed ANOVA-tables can be found in the Appendix I. 


\section{Results}

Stone content for within plot ranged from $21 \%$ to $49 \%$, indicating a medium-high stone content (Table 5) (Viro 1952). Soil textural class was identified as fine sand (USDA sandy loam, FIN fine sand) and predominant humus type as moder. Humus thickness was higher in the CH plots than for WTH ( $<<0.059$, data not shown) plots whereas bulk density remained relatively unchanged after the treatment. Table 5 demonstrates that the clay content at the experimental site was fairly high in the mineral soil, which is in contrast to typical soils in Finland (Tamminen 2009).

\subsection{Total elemental pools}

Total elemental pools of C, N, Ca and P pools $\left(\mathrm{kg} \mathrm{ha}^{-1}\right)$ tended to be lower after WTH in both soil horizons (Table 6). WTH reduced significantly the amount of organic matter $($ LOI \%) $(\mathrm{p}<0.002)$ in the organic layer. Consequently, WTH resulted in lower total C and $\mathrm{N}$ pools in the organic layer ( $\mathrm{p}<0.067$ and $\mathrm{p}<0.057$, respectively). A trend was observed in the mineral soil where, WTH significantly reduced total $N$ pool $(p<0.032)$ and affected total $\mathrm{C}$ pool $(\mathrm{p}<0.070)$. In the organic layer, however, treatment effect on total pools was significant only for $\mathrm{Ca}(\mathrm{p}<0.011)$. K pools increased slightly after WTH in both layers. Under WTH, Mg decreased in the organic layer but increased in the mineral soil. There was a marginal difference between treatments on $\mathrm{C} / \mathrm{N}$-ratio. The concentrations of $\mathrm{C}$ and $\mathrm{N}(\mathrm{C}$ and $\mathrm{N} \%)$ also decreased after WTH $(\mathrm{p}<0.036$ and $\mathrm{p}<$ 0.05 , respectively) in the forest floor. A similar tendency was evident for $\mathrm{C}$ and $\mathrm{N}$ concentrations in the mineral soil but it was not statistically significant.

\subsection{Exchangeable nutrient pools}

WTH decreased the pools of exchangeable $\mathrm{Ca}, \mathrm{K}$ and $\mathrm{Mg}$ ( $\mathrm{kg}$ ha-1) in the organic layer, whereas the pools of exchangeable $\mathrm{Al}$ and $\mathrm{Fe}$ increased (Table 7). The change was significant for $\mathrm{Al}(\mathrm{p}<0.000), \mathrm{Fe}(\mathrm{p}<0.001)$ and $\mathrm{Ca}(\mathrm{p}<0.009)$. The pools of exchangeable $\mathrm{Ca}(\mathrm{p}<0.000)$ and $\mathrm{Mg}(\mathrm{p}<0.003)$ declined significantly in the mineral soil 
as result of WTH. Ratios of $\mathrm{Ca}$ and $\mathrm{Mg}$ to $\mathrm{Al}$ were significantly higher in the $\mathrm{CH}$ in the organic layer $(\mathrm{p}<0.000$ and $\mathrm{p}<0.000)$. A similar treatment effect was evident in the mineral layer where $\mathrm{Ca} / \mathrm{Al}(\mathrm{p}<0.004), \mathrm{Ca} / \mathrm{Mg}(\mathrm{p}<0.009)$ and $\mathrm{Mg} / \mathrm{Al}$-ratios $(\mathrm{p}<0.044)$, all significantly decreased.

\subsection{Soil acidity and cation exchange capacity}

Harvest methods had no significant effect on $\mathrm{pH}$ in either soil horizon (Table 8). Effective cation exchange capacity $\left(\mathrm{ECEC}, \mathrm{cmol}_{(+)} \mathrm{kg}^{-1}\right)(\mathrm{p}<0.009)$ and base saturation $(\mathrm{BS} \%)(\mathrm{p}<0.000)$ were both lower after WTH in the organic layer. Correspondingly, exchangeable acidity $\left(\mathrm{EA}, \mathrm{cmol}_{(+)} \mathrm{kg}^{-1}\right)(\mathrm{p}<0.002)$ increased significantly in the organic layer as result of WTH. Significant treatment effect on ECEC and BS was also detected in the mineral soil ( $\mathrm{p}<0.016$ and $\mathrm{p}<0.004$, respectively). However, treatment had no effect on EA in the mineral soil. pH was not affected by harvest intensity (Table 8). 


\section{Discussion}

Harvesting equipment causes disturbance to the forest floor and upper layers of the mineral soil through mixing and redistribution of the soil matter. Mixing of mineral soil into the organic layer was evident in many of the sample plots at the study site. The extent of the disturbance varied from light scarification to deep wheel ruts and affected 10 to $60 \%$ of the study area. The soil samples were collected from the undisturbed areas of the site, i.e. wheel ruts were avoided. The plots that were most disturbed were removed from the total pool analysis $(17 \& 18)$. Furthermore, all the sample plots had abundant ground vegetation, dominated by grasses (Deschampsia flexuosa) and herbs, which made the identification of the different soil layers difficult. Similar developments have been observed at fertile conifer clear-cuts in Sweden (Olsson and Staaf 1995, Olsson et al. 1996b).

The results of this study showed no evidence that WTH would result in reduced soil organic carbon or total nitrogen pools $\left(\mathrm{kg} \mathrm{ha}^{-1}\right)$ ten years after the final felling. However, a significant decrease in organic matter concentration $(\%)(p<0.002)$ (Table 6) was observed in the organic layer after WTH and similar tendency was evident in the mineral soil $(\mathrm{p}<0.098)$. This result is in contrast with other long-term studies, which have shown no or little effect of final felling harvest intensity on soil organic matter content (Johnson et al. 1991b, Olsson et al. 1996b, Johnson et al. 2002, Walmsley et al. 2009, Vanguelova et al. 2010, Wall and Hytönen 2011). A Canadian study showed a loss of C content from the forest floor three years after WTH (Bélanger et al. 2003). Johnson et al. 1991b reported a higher OM-content in the mineral soil after $\mathrm{WTH}$, owing to the mixing of the soil horizons during harvest and redistribution of OM in the soil profile. Therefore they concluded that there was no net loss of OM in the profile (Johnson et al. 1991b). In this study, OM content was reduced after WTH (Table 6). Olsson et al. (1996b) observed a decrease in the $\mathrm{C}$ pool in the humus layer at a Norway spruce clear-cut site, but an increase deeper in the mineral soil and they too concluded that OM is partly decomposed 
and partly transported downwards in the soil profile after the harvest. In the current study only the upper layer of the mineral soil $(0-10 \mathrm{~cm})$ was sampled, thus making the comparison with the above-mentioned studies problematic (Johnson et al. 1991b, Olsson et al. 1996b).

Although not statistically significant, the thickness of the humus layer was reduced by the WTH harvest (Table 5). Clear-cut per se affects the thickness of the humus layer (Prescott et al. 2000), but these results suggest that the intensity of the harvest has a tendency to amplify this phenomenon. No treatment effect was detected on soil $\mathrm{C} / \mathrm{N}$ ratios, indicating that the harvest intensity did not have an influence on the quality of the organic matter (Table 6). This is in agreement with the findings of other studies of similar time scope (Olsson et al. 1996b, Saarsalmi et al. 2010). The concentrations of C and N (\%) (Table 6) were both reduced ( $\mathrm{p}<0.036$ and $\mathrm{p}<0.05)$ in the organic layer and tended to be lower in the mineral soil after WTH. This was reflected in the $\mathrm{C} / \mathrm{N}$-ratio, as the concentrations and $\mathrm{C} / \mathrm{N}$-ratio were measured from the same samples.

The pools of total $\mathrm{K}, \mathrm{Mg}, \mathrm{P}$ and $\mathrm{Ca}\left(\mathrm{kg} \mathrm{ha}^{1}\right)$ (Table 6) were generally not affected by harvest intensity, apart from the $\mathrm{Ca}$ pool, which was significantly lower in the organic layer $(\mathrm{p}<0.011)$ after WTH. The exchangeable pool of Ca (Table 7) decreased significantly in both soil layers ( $p<0.009$ and $\mathrm{p}<0.000$, respectively) at the WTH plots. Pools of exchangeable $\mathrm{Al}$ and $\mathrm{Fe}$ on the other hand increased in the organic layer $(\mathrm{p}<0.000$ and $\mathrm{p}<0.001)$ but remained somewhat unchanged in the mineral soil. Several other studies have also reported reductions in the exchangeable pools of $\mathrm{Ca}$ in the organic layer soon after WTH (Nykvist and Rosen 1985, Johnson et al. 1991a, Thiffault et al. 2006). Ca reductions have also been reported in long-term studies; Olsson et al. (1996a) reported a significant loss of Ca 15-16 years after WTH in a Southern Swedish Norway spruce stand and Saarsalmi et al. (2010) observed a similar trend 22 years after WTH in Scots pine stand in Finland. In England, Walmsley et al. (2009) found a decrease in the organic layer pool of exchangeable Ca but an increase in the lower mineral horizon pool in a second generation WTH Sitka spruce (Picea 
sitchensis) stand, implying that the $\mathrm{Ca}$ is translocated within the soil profile. Due to its immobility $\mathrm{Ca}$ is retained longer in the logging residue and released relatively slowly in decomposition (Palviainen et al. 2004a). Thus a large proportion of the Ca released is captured by the forest floor and emerging vegetation (Palviainen et al. 2005, Thiffault et al. 2006, Vanguelova et al. 2010). Swedish studies have shown changes in needle nutrient concentrations (Olsson et al. 2000) and reductions in the growth the new tree generation (Egnell and Leijon 1999) as a result of nutrient depletion caused by WTH. The effects of the treatment were more apparent for the divalent cations, $\mathrm{Ca}$ and $\mathrm{Mg}$, than for monovalent $\mathrm{K}$ (Table 7). The exchangeable $\mathrm{K}$ pool remained unchanged in the organic layer but was reduced in the mineral soil, thus the overall pool of the upper soil layer (org + min) was reduced (Table 7). Bélanger et al. (2003) observed an increased flux of K into the mineral soil after WTH in a conifer stand in Canada. They concluded that the increased $\mathrm{K}$ activity was caused by mulching during harvest (Bélanger et al. 2003). Most of the $\mathrm{K}, \mathrm{Al}$ and $\mathrm{Fe}$ is released from the logging residue within years of the harvest (Fahey et al. 1991, Hyvönen et al. 2000, Palviainen et al. 2004a). Ca, in contrast, is effectively retained in the woody litter for a longer time following harvest, implying that branches could serve as longer-term source of Ca (Fahey et al. 1991, Palviainen et al. 2004a). Based on the above, we can assume that most of $\mathrm{K}, \mathrm{Al}$ and $\mathrm{Fe}$ had been released from the residue on the $\mathrm{CH}$ plots the time of sampling, whereas $\mathrm{Ca}$ was still retained in the decomposing biomass.

Effective cation exchange capacity (ECEC $\mathrm{cmol}_{+} \mathrm{kg} \mathrm{ha}^{-1}$ ) and base saturation (BS \%) were both significantly higher in the organic layer and mineral soil if the logging residues were retained after the harvest (Table 8). The negative developments in the organic layer at the WTH plots are probably the result of reduced OM content and changes in the acidtp-base-cation ratios. After WTH, a much larger proportion of the ECEC was accounted for by acid cations in both layers (increased acid saturation) (Table 8). The decreased $\mathrm{Ca} / \mathrm{Al}$-ratio indicates that WTH resulted in displacement of $\mathrm{Ca}$ from the exchange sites by $\mathrm{Al}$ in the organic layer. The decrease of BS and ECEC in the mineral soil could be the result of loss of exchangeable $\mathrm{Ca}$ from the layer. Since EA remained virtually unaffected 
by the harvest intensity in the mineral layer, we can assume that exchange sites were occupied by another base cation after WTH. The ratios of base cations to acid cations were significantly smaller after WTH compared to $\mathrm{CH}$ (Table 7). Higher Al concentrations, and lower $\mathrm{Ca}$ and $\mathrm{Mg}$ concentrations imply that the soil was acidified as a consequence of the WTH. Exchangeable acidity did in fact increase significantly in the organic layer after WTH (Table 8). Soil acidity largely depends on the net charges of $\mathrm{H}^{+}$ and as no increase in the abundance of $\mathrm{H}^{+}$ions was detected (Table 17), we could conclude that increased $\mathrm{Al}$ activity is mainly responsible for the increased acidity in the organic layer. Furthermore, $\mathrm{pH}$ (Table 8) was not affected by the harvest intensity. A similar trend was observed by Olsson et al. (1996a) thus leading them to conclude that $\mathrm{pH}_{\mathrm{H} 2 \mathrm{O}}$ appears to be less sensitive to changes in the $\mathrm{BS}$ and $\mathrm{EA}$. Yet if $\mathrm{pH}$ remains unchanged it is possible that the soil still possesses sufficient buffering capacity after WTH (Saarsalmi et al. 2010).

The soil at the experimental site was sampled in 1979, 1984 and 1989 by the Finnish Forest Research Institute. However, due to differences in methods used for chemical analysis, only the results from the 1989 sampling of the organic layer were compatible with the current results. Table 9 indicates that apart from exchangeable $\mathrm{K}$, all the elemental pools appear to have decreased as a result of WTH with the relative (\%) reduction being highest for total $\mathrm{C}, \mathrm{N}$ and $\mathrm{Ca}$ whereas $\mathrm{C} / \mathrm{N}$ remains relatively unchanged. These results support the hypothesis that in the long-term WTH could deplete forest soil fertility through intensified base cation loss. The experimental site was thinned twice before the final felling and significant quantities of biomass were removed from the WTH plots, thus implying that nutrient inputs into the system have reduced (Table 3 and Table 4). Nevertheless, it remains unclear whether WTH could have cumulative effects on the soil nutrient capital. 


\subsection{Silvicultural implications}

The surface soil provides a large base for plant-nutrition in the boreal forest ecosystems; understanding the changes caused by WTH, is therefore of particular interest from a forest management perspective (Worrell and Hampson 1997, Prescott et al. 2000). WTH removes large quantities of biomass from a stand, resulting in several-fold increases in nutrient exports compared to CH (Raulund-Rasmussen et al. 2008, Palviainen and Finér 2012). Nutrient balance calculations in Sweden have indicated that WTH could result in base cation depletion after only one rotation (Sverdrup and Rosen 1998, Akselsson et al. 2007), and a more recent modeling study showed a similar trend in Finland (Palviainen and Finér 2012). Nutrient losses are compensated over time through mineral weathering and atmospheric deposition; however, the removals associated with WTH often exceed natural inputs expected during a harvest rotation (Sverdrup and Rosen 1998, Akselsson et al. 2007, Palviainen and Finér 2012). Longer rotation times could buffer against the nutrient losses (Kimmins 1977, Worrell and Hampson 1997). Considering that the rotation time on average in Scandinavia are already are fairly long (more than 60 yrs.), prolonging them does not seem feasible within current management practices. Several studies have reported growth losses after thinnings (Jacobson et al. 2000, Helmisaari et al. 2011). Tree growth reactions have been ascribed to changes in soil nutrient pools and nutrient removals associated with the logging residue removals. WTH thinned stands have been reported to respond positively to compensatory fertilization (NPK), implying that the growth losses associated with WTH could be compensated with fertilization (Olsson 1999, Jacobson et al. 2000).

Several studies have reported site- and species-specific interactions associated with WTH (Olsson et al. 1996b, Thiffault et al. 2006, Raulund-Rasmussen et al. 2008, Wall and Hytönen 2011). Thiffault et al. (2006) found that Jack pine (Pinus banksiana), Black spruce (Picea mariana) and Balsam fir (Abies balsamea) all react differently to harvesting intensity, leading them to conclude that the selection of species could determine a site's sensitivity to WTH. Smolander et al. (2010) reported higher C 
mineralization/ $\mathrm{N}$ mineralization ratios when logging residues were kept on site, indicating that the presence of residues facilitate the mineralization of $\mathrm{N}$ on the less fertile sites. Soils in the more fertile sites (i.e. more productive sites) tend to be more resistant to the changes in acidity due to their higher buffering capacity. Thus the benefits of retaining logging residue on site might be limited to locations with lower OM pools (Thiffault et al. 2006, Tamminen et al. 2012). Furthermore, the potential negative effects of WTH will be highest on sites where a large proportion of the nutrient capital is in trees, i.e. on sites with fertile soils (Kimmins 1977, Worrell and Hampson 1997). From a forest management perspective maintaining long-term site productivity is essential, and the results from this study imply that WTH could result in losses of site productivity even at a fertile Norway spruce site. The possibility of leaving green needles on site (seasoning) after clear-cutting has been discussed as a method to minimize the removal of nutrients but the results of such efforts have been mixed (Olsson et al. 1996b, Wall 2008). Such logging residue removal in phases also would increase the traffic at the stand, potentially causing soil compaction and damages to the forest floor. One alternative could be to plant conifer trees in mixes with broadleaves, which are known to improve the nutrient status of the soil (Thelin et al. 2002, Paré et al. 2002).

Scientific research tends to utilize results from controlled experiments, which are not entirely applicable in practical forestry (Egnell 2011, Tamminen et al. 2012). In this experiment all the logging residues were removed from the site whereas in practice approximately $20-30 \%$ of the logging residues in WTH are left on the harvest sites due to operational limitations (Nurmi 2007, Peltola et al. 2011), resulting in more nutrients being left in the stand in the form of logging residue after WTH.

Conclusively, there is a need for long-term WTH experiments that cover a large range of different site types and tree species and extend over a whole rotation (Thiffault et al. 2011, Egnell 2011). 


\subsection{Reliability of the results}

One time sampling in general is inferior to pre-and post-treatment sampling (Tamminen

et al. 2012). The sampling precision was not tested in this study; however, the relatively large standard errors of the elemental pools imply that there was a large spatial variability in the soils (Table 6 and Table 7). Concentrations and $\mathrm{C} / \mathrm{N}$ ratios tend to have a smaller error than the elements measured directly from the sample (Saarsalmi et al. 2010) as was evident in this study. The higher standard errors for the total and exchangeable pools are the result of the large variation in the humus layer thickness for the organic layer and stone content in the mineral soil. 


\section{Conclusion}

The results of this study indicate that whole-tree harvest can exacerbate loss of nutrient cations and soil acidification, particularly in the organic layer of the soil ten years after final harvest in a fertile Norway spruce stand in comparison to conventional harvest. Exchangeable acidity, exchangeable $\mathrm{Al}$ concentration and $\mathrm{Ca} / \mathrm{Al}$-ratio increased significantly in the organic layer at the plots from which the logging residues were removed. Significant reductions in the effective cation exchange capacity and base saturation were also observed across the upper soil layers after WTH. The removal of logging residues did not affect the $\mathrm{C} / \mathrm{N}$ ratio or total pools of carbon and nitrogen in either soil layer. Pools of exchangeable and total $\mathrm{Ca}$ were significantly reduced as a result

of WTH. These findings suggest that WTH can cause depletion of base cations from the upper soil layers. Thus, although the stand possesses significant pools of nutrients at present, continued WTH could have long-term effects on site productivity.

The observed decline in the exchangeable nutrient pools at the study site indicates that the potential detrimental effects of WTH on soil productivity are not only limited to nutrient poor sites. Furthermore, if WTH is practiced throughout the entire rotation the nutrient outputs (biomass removals) could exceed the inputs (deposition and weathering) resulting in nutrient depletion. 


\section{Figures}

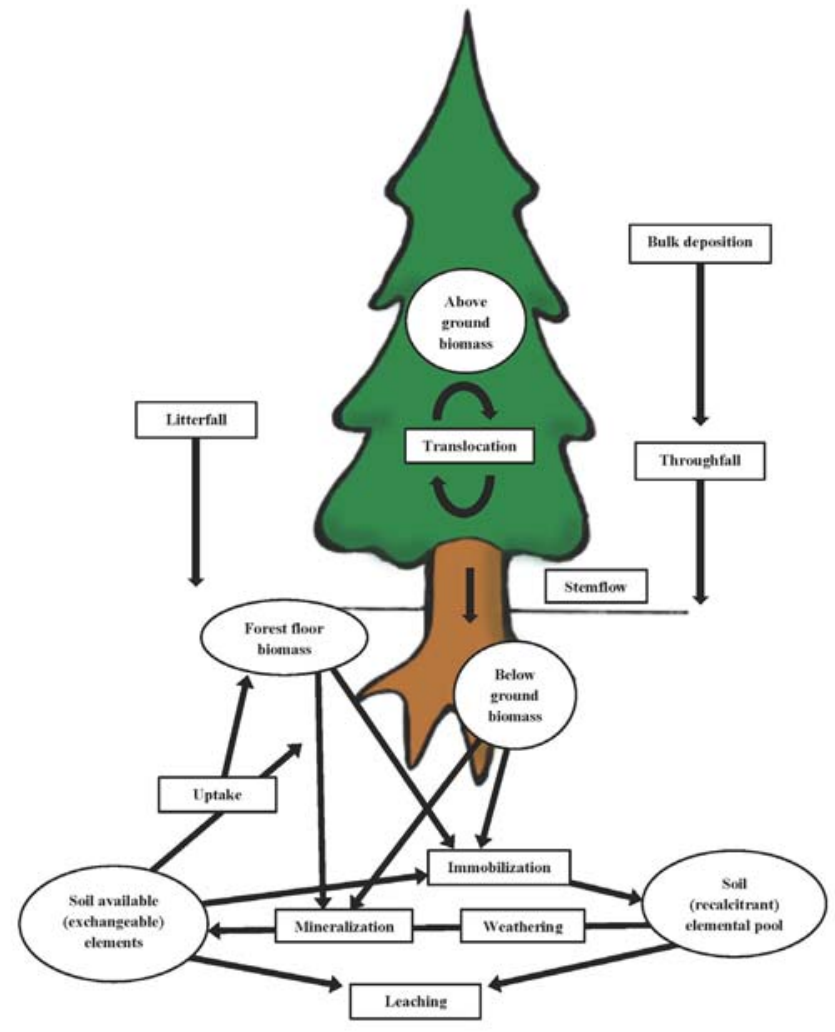

Figure 3 Nutrient dynamics in a typical Norway spruce stand (Modified from Likens \& Bormann 1995, Piirainen 2002) 


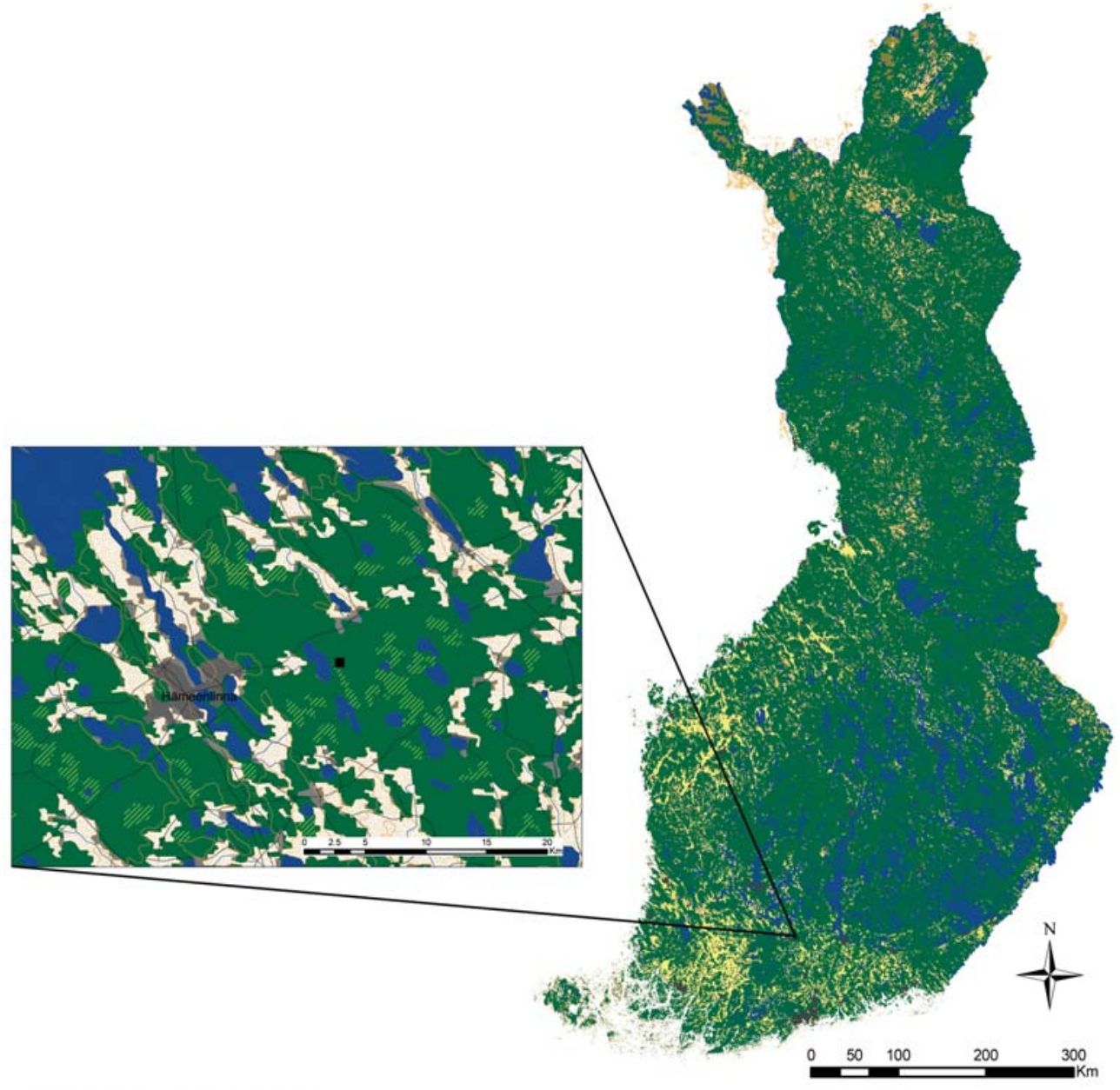

(C) MML 2012

Figure 4 The site location in Janakkala, Southern Finland (Data source: National Land Survey of Finland-Appendix II includes the licence) 


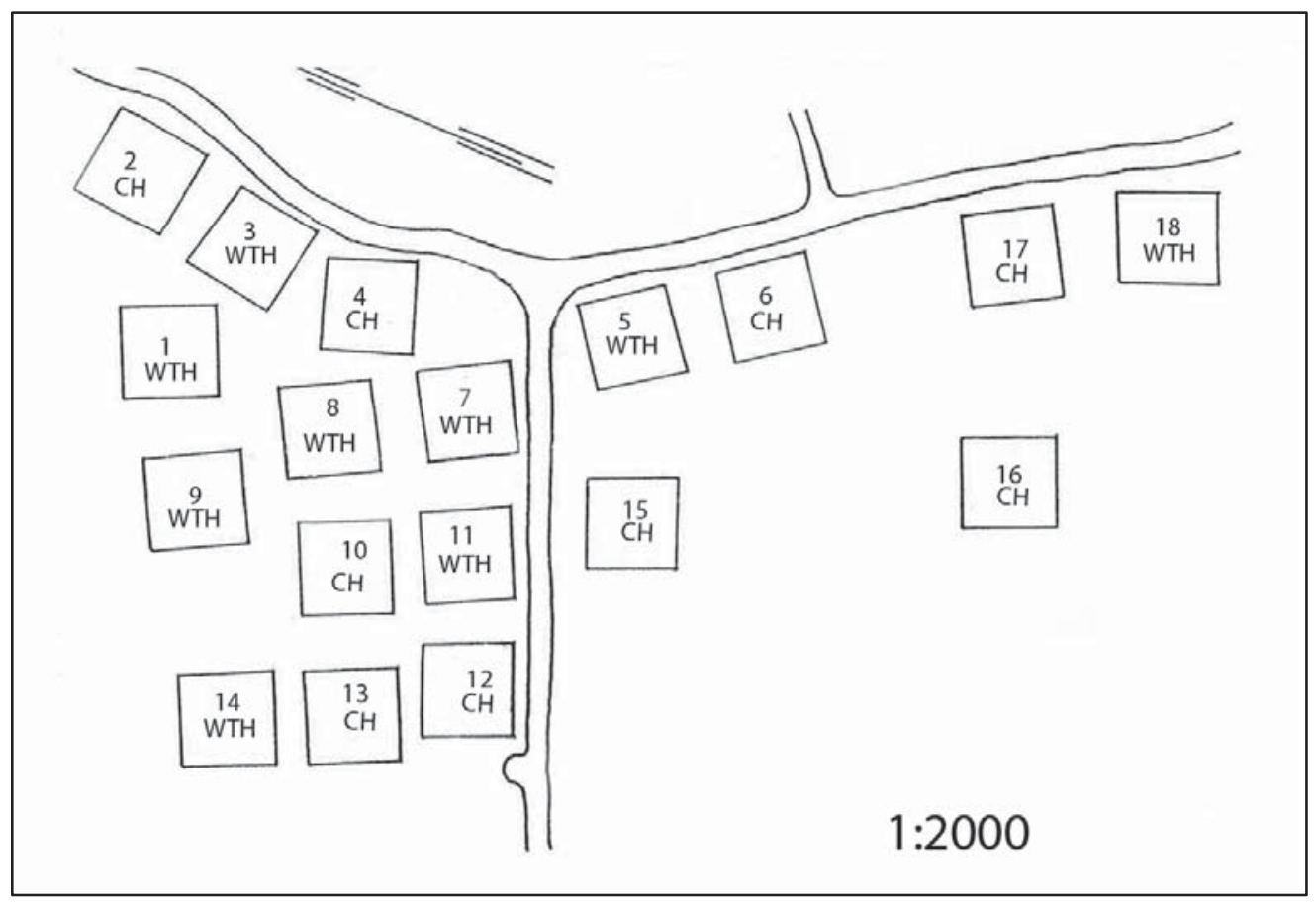

Figure 5 The size of each plot is $30 \times 30 \mathrm{~m}$, surrounded by a five-meter buffer zone (Illustration: L. Kaarakka) 


\section{Tables}

Table 1 Nitrogen $(\mathrm{N})$, potassium $(\mathrm{K})$ and calcium $(\mathrm{Ca})$ deposition, weathering, leaching and total and exchangeable pools in the organic layer and mineral soil in Finland (Starr et al. 1998, Ruoho-Airola et al. 2003, Piirainen et al. 2004, Palviainen 2005, Helmisaari et al. 2008, Palviainen and Finér 2012). Stars indicate missing data

\begin{tabular}{lccc}
\hline & $\mathbf{N}$ & $\mathbf{K}$ & $\mathbf{C a}$ \\
\hline $\begin{array}{l}\text { Deposition }\left(\mathrm{kg} \mathrm{ha}^{-1} \mathrm{yr}^{-1}\right) \\
\text { Weathering }\left(\mathrm{kg} \mathrm{ha}^{-1} \mathrm{yr}^{-1}\right)\end{array}$ & $2-6$ & $0.3-0.6$ & $0.3-2.1$ \\
Leaching $\left(\mathrm{kg} \mathrm{ha}^{-1} \mathrm{yr}^{-1}\right)$ & $0.29-2.3$ & $0.5-2.5$ & $1.95-14.8$ \\
& & & \\
\hline Total pools $\left(\mathrm{kg} \mathrm{ha}^{-1}\right)$ & & $*$ & $*$ \\
$\quad$ Organic layer & 600 & & \\
Mineral soil $(0-20 \mathrm{~cm})$ & $920-2650$ & $380-605$ & $852-1440$ \\
Plant-available pools & & & \\
$\quad$ Organic layer & $*$ & 36 & 140 \\
Mineral soil $(0-20 \mathrm{~cm})$ & $6-18$ & $32-110$ & $75-730$ \\
\hline
\end{tabular}


Table 2 The experimental design of the thinning experiment (old) and final-felling experiment (new)

\begin{tabular}{cccc}
\hline \multicolumn{1}{c}{ Old treatment } & New treatment & Plots \\
\hline $\begin{array}{c}\text { Conventional harvest } \\
(\mathrm{CH})\end{array}$ & $\mathrm{CH}_{1}+\mathrm{CH}_{2}$ & $\mathrm{CH}_{3}$ & $2,15,17$ \\
$\mathrm{CH}$ with fertilization & $\mathrm{CH}_{1}+\mathrm{F}_{1}+\mathrm{CH}_{2}+\mathrm{F}_{2}$ & $\mathrm{CH}_{3}$ & $6,12,16$ \\
$\begin{array}{c}\mathrm{CH} \text { with additional } \\
\text { logging residue } \\
\begin{array}{c}\text { Whole-tree harvest } \\
\text { (WTH) }\end{array}\end{array}$ & $\mathrm{CH}_{1}+\mathrm{LG}_{1}+\mathrm{CH}_{2}+\mathrm{LG}_{2}$ & $\mathrm{CH}_{3}$ & $4,10,13$ \\
$\begin{array}{c}\text { WTH with } \\
\text { compensatory } \\
\text { fertilization } \\
\begin{array}{c}\text { WTH with } \\
\text { fertilization }\end{array}\end{array}$ & $\mathrm{WTH}_{1}+\mathrm{WTH}_{2}$ & $\mathrm{WTH}_{3}$ & $5,11,18$ \\
\hline
\end{tabular}


Table 3 The estimated mass of logging residue mass $\left(\mathrm{kg} \mathrm{ha}^{-1}\right)$ and nutrients contents $\left(\mathrm{kg} \mathrm{ha}^{-1}\right)$ removed or retained at the experimental site during thinnings (Helmisaari et al. 2011)

\begin{tabular}{ccccccc}
\hline & Mass & C & N & Ca & K & P \\
\cline { 2 - 7 } & \multicolumn{7}{c}{$\mathbf{k g ~ h a}^{-1}$} \\
\hline $1^{\text {st }}$ thinning & 17323 & 7276 & 85 & 76 & 27 & 7 \\
$2^{\text {nd }}$ thinning & 12965 & 5445 & 89 & 71 & 23 & 7 \\
\hline
\end{tabular}


Table 4 Estimated mass $\left(\mathrm{kg} \mathrm{ha}^{-1}\right)$ and nutrient content of logging residues retained $(\mathrm{CH})$ and removed (WTH) from each plot at final felling (Hakkila et al. 1998)

\begin{tabular}{|c|c|c|c|c|c|c|c|}
\hline \multirow{2}{*}{ Plot } & \multirow{2}{*}{ Treatment } & Mass & C & $\mathbf{N}$ & $\mathrm{Ca}$ & $\mathbf{K}$ & $\mathbf{P}$ \\
\hline & & \multicolumn{6}{|c|}{$\operatorname{kg~ha}^{-1}$} \\
\hline 2 & $\mathrm{CH}$ & 38548 & 16190 & 237 & 175 & 84.7 & 27.7 \\
\hline 4 & $\mathrm{CH}$ & 40608 & 17055 & 231 & 171 & 82.8 & 27.1 \\
\hline 6 & $\mathrm{CH}$ & 51489 & 21625 & 245 & 182 & 87.8 & 28.7 \\
\hline 10 & $\mathrm{CH}$ & 40955 & 17201 & 241 & 178 & 86.2 & 28.2 \\
\hline 12 & $\mathrm{CH}$ & 52072 & 21870 & 257 & 191 & 92.1 & 30.1 \\
\hline 13 & $\mathrm{CH}$ & 33865 & 14223 & 260 & 193 & 93.0 & 30.4 \\
\hline 15 & $\mathrm{CH}$ & 40141 & 16859 & 219 & 162 & 78.4 & 25.6 \\
\hline 16 & $\mathrm{CH}$ & 47324 & 19876 & 226 & 168 & 81.0 & 26.5 \\
\hline \multirow[t]{2}{*}{17} & $\mathrm{CH}$ & 45453 & 19090 & 239 & 177 & 85.6 & 28.0 \\
\hline & Mean & 43384 & 18221 & 239.6 & 177.5 & 85.7 & 28.1 \\
\hline 1 & WTH & 46706 & 19617 & 271 & 201 & 97.1 & 31.8 \\
\hline 3 & WTH & 34418 & 14455 & 192 & 142 & 68.7 & 22.5 \\
\hline 5 & WTH & 42239 & 17741 & 258 & 191 & 92.4 & 30.2 \\
\hline 7 & WTH & 49139 & 20638 & 252 & 187 & 90.3 & 29.5 \\
\hline 8 & WTH & 45575 & 19142 & 232 & 172 & 83.0 & 27.1 \\
\hline 9 & WTH & 37518 & 15758 & 252 & 186 & 90.0 & 29.5 \\
\hline 11 & WTH & 36508 & 15333 & 237 & 176 & 85.0 & 27.8 \\
\hline 14 & WTH & 53592 & 22509 & 262 & 194 & 93.8 & 30.7 \\
\hline \multirow[t]{2}{*}{18} & WTH & 36761 & 15439 & 233 & 173 & 83.5 & 27.3 \\
\hline & Mean & 42495 & 17848 & 243 & 180.3 & 87.1 & 28.5 \\
\hline
\end{tabular}


Table 5 Humus thickness $(\mathrm{cm})$, bulk density of the mineral soil samples $\left(\mathrm{g} \mathrm{cm}^{-3}\right)$, particle size distribution of the fine-earth (\%), gravel content (\%) and stone content (\%) in the sampled plots

\begin{tabular}{cccccccc}
\hline Plot & Treatment & $\begin{array}{c}\text { Humus } \\
\text { thickness }\end{array}$ & $\begin{array}{c}\text { BD g } \\
\mathbf{c m}^{-3}\end{array}$ & Clay \% & $\begin{array}{c}\text { Fine } \\
\text { earth } \\
\text { \% }\end{array}$ & Gravel \% & Stone \% \\
\hline 2 & CH & 4.60 & 0.722 & 3.98 & 30.2 & 24.2 & 42.4 \\
4 & CH & 2.68 & 0.699 & 2.06 & 34.3 & 40.3 & 28.9 \\
6 & CH & 2.88 & 0.613 & 4.45 & 33.4 & 34.3 & 17.7 \\
10 & CH & 2.00 & 0.619 & 3.75 & 44.1 & 23.6 & 23.4 \\
12 & CH & 3.16 & 0.775 & 4.33 & 38.0 & 38.2 & 38.2 \\
13 & CH & 2.16 & 0.70 & 3.07 & 47.7 & 28.6 & 31.2 \\
15 & CH & 2.00 & 0.646 & 5.84 & 35.1 & 27.2 & 21.4 \\
16 & CH & 3.72 & 0.599 & 4.01 & 34.7 & 31.2 & 46.7 \\
17 & CH & 3.00 & 0.744 & 5.40 & 42.0 & 20.2 & 22.1 \\
& Mean & 2.91 & 0.68 & 4.10 & 37.7 & 29.8 & 30.2 \\
1 & WTH & 2.52 & 0.69 & 4.15 & 37.2 & 22.2 & 35.7 \\
3 & WTH & 2.48 & 0.672 & 3.72 & 46.2 & 18.2 & 27.0 \\
5 & WTH & 2.76 & 0.606 & 3.78 & 48.0 & 12.5 & 26.0 \\
7 & WTH & 2.32 & 0.681 & 3.68 & 48.3 & 58.8 & 48.8 \\
8 & WTH & 2.64 & 0.753 & 4.03 & 38.7 & 33.2 & 24.7 \\
9 & WTH & 2.08 & 0.803 & 3.32 & 51.9 & 24.7 & 32.4 \\
11 & WTH & 1.96 & 0.538 & 3.02 & 38.2 & 37.6 & 42.2 \\
14 & WTH & 2.00 & 0.707 & 4.01 & 40.9 & 37.9 & 38.8 \\
18 & WTH & 1.84 & 0.896 & 6.53 & 51.6 & 32.4 & 24.5 \\
& Mean & 2.29 & 0.71 & 4.02 & 44.5 & 30.8 & 33.3 \\
\hline
\end{tabular}




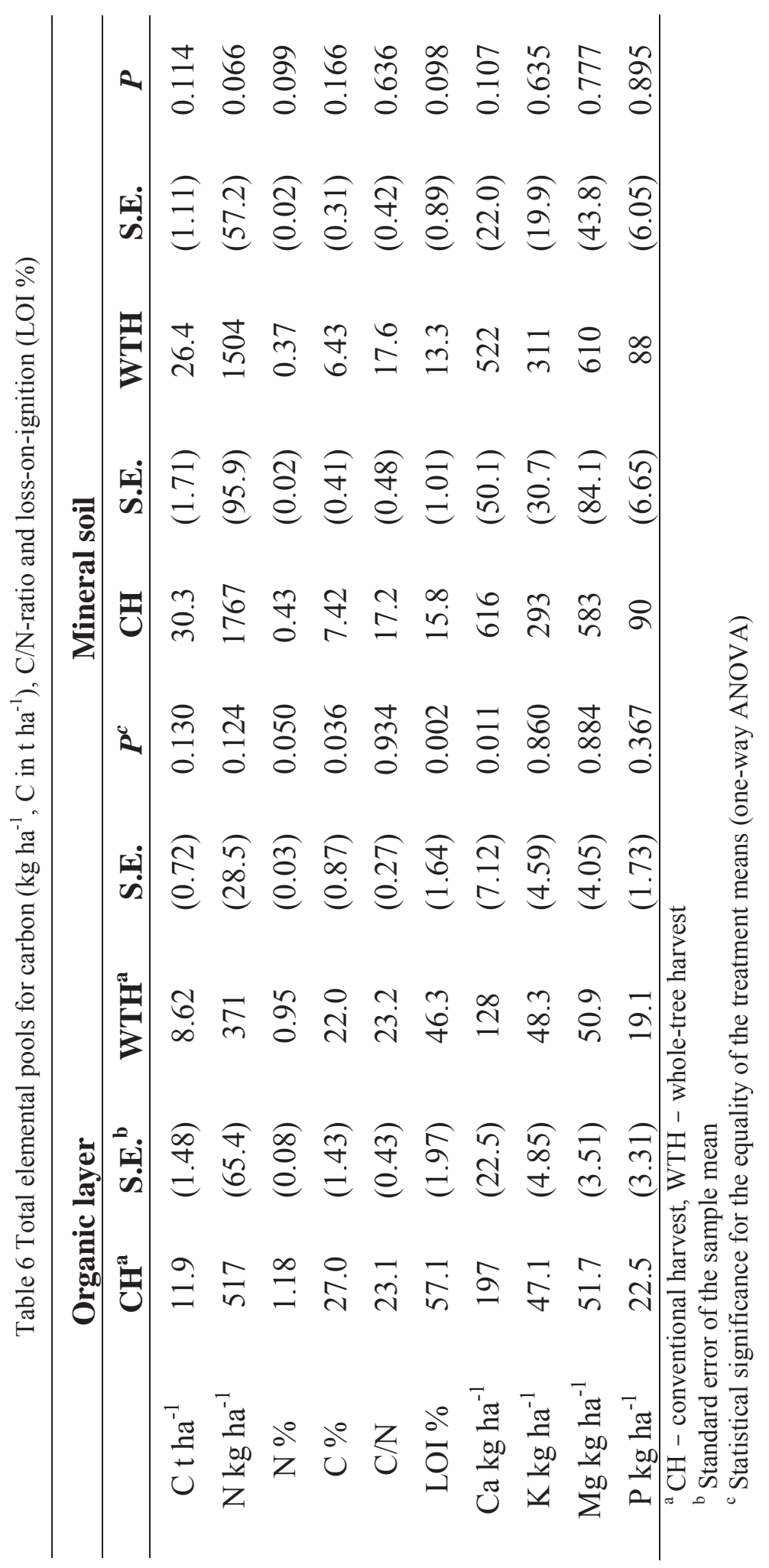




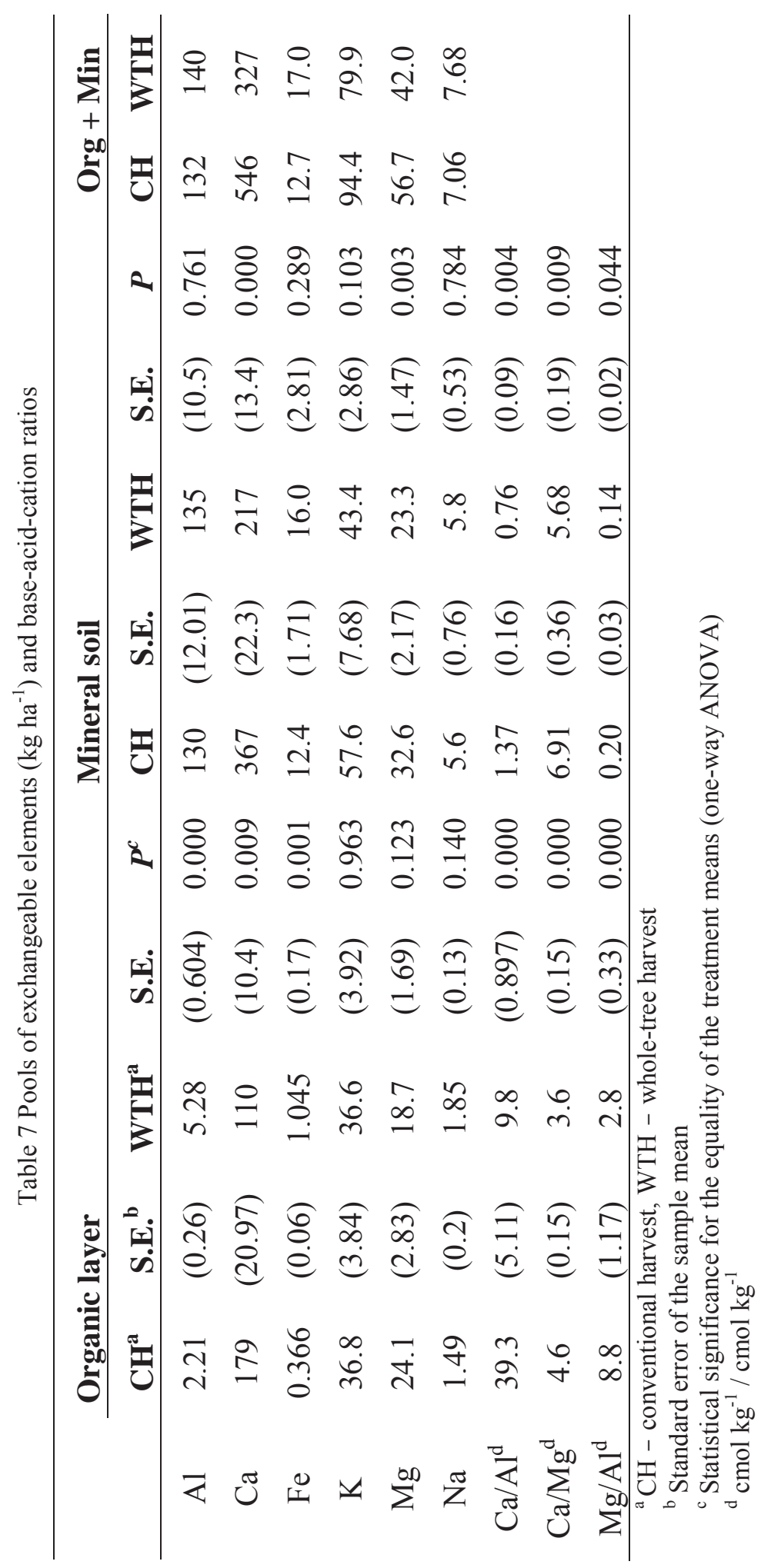




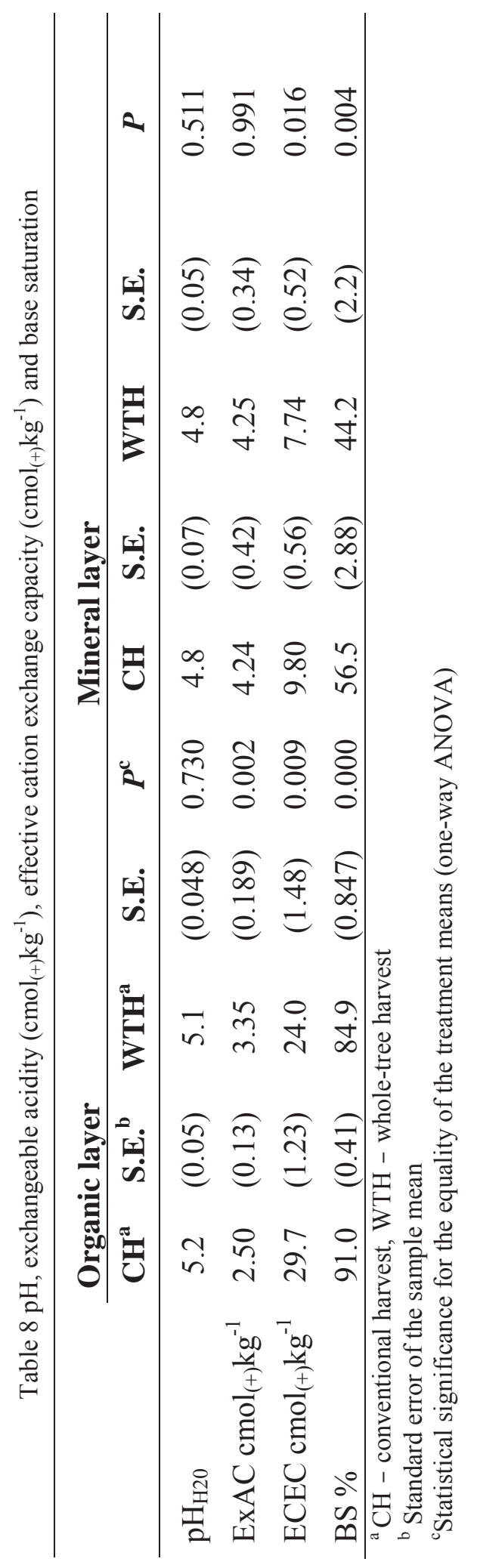


Table $9 \mathrm{C} / \mathrm{N}$-ratio and total elemental pools $\left(\mathrm{kg} \mathrm{ha}^{-1}, \mathrm{C}\right.$ in $\left.\mathrm{t} \mathrm{ha}^{-1}\right)$ of the organic layer in 1989 and 2011 with their relative difference

\begin{tabular}{lccc}
\hline & Year & CH & Organic layer \\
\cline { 2 - 4 } $\mathrm{C} / \mathrm{N}$ & 1989 & 26.92 & 27.39 \\
& 2011 & 23.07 & 23.19 \\
$\mathrm{C} \mathrm{t} \mathrm{ha}^{-1}$ & Change $\%$ & -14 & -15 \\
& 1989 & 15400 & 14372 \\
& 2011 & 11855 & 8624 \\
$\mathrm{~N} \mathrm{~kg} \mathrm{ha}^{-1}$ & Change $\%$ & -23 & -40 \\
& 1989 & 572 & 525 \\
& 2011 & 517 & 371 \\
$\mathrm{Ca} \mathrm{kg} \mathrm{ha}^{-1}$ & Change $\%$ & -9.6 & -29 \\
& 1989 & 191 & 159 \\
& 2011 & 197 & 128 \\
$\mathrm{~K} \mathrm{~kg} \mathrm{ha}^{-1}$ & Change $\%$ & +3.2 & -19 \\
& 1989 & 41.0 & 47.6 \\
& 2011 & 47.1 & 48.3 \\
& Change $\%$ & +15 & +1.6 \\
$\mathrm{Mg} \mathrm{kg} \mathrm{ha}^{-1}$ & 1989 & 66.9 & 75.9 \\
& 2011 & 51.7 & 50.9 \\
& Change $\%$ & -23 & -33 \\
\hline
\end{tabular}




\section{Appendix I}

Table 10 One-way ANOVA for the treatment effect on total elemental pools in the organic layer.

\begin{tabular}{|c|c|c|c|c|c|c|}
\hline & & Sum of Squares & df & Mean Square & $\mathbf{F}$ & $\mathbf{p}$ \\
\hline \multirow[t]{3}{*}{$\mathrm{C} \mathrm{kg} \mathrm{ha}^{-1}$} & Between Groups & 34969637 & 1 & 34969637 & 2.592 & 0.13 \\
\hline & Within Groups & 188864459 & 14 & 13490318 & & \\
\hline & Total & 223834096 & 15 & & & \\
\hline \multirow[t]{3}{*}{$\mathrm{N} \mathrm{kg} \mathrm{ha}^{-1}$} & Between Groups & 67865 & 1 & 67865 & 2.673 & 0.124 \\
\hline & Within Groups & 355413 & 14 & 25387 & & \\
\hline & Total & 423278 & 15 & & & \\
\hline \multirow[t]{3}{*}{$\mathrm{N} \%$} & Between Groups & 0.1 & 1 & 0.117 & 4.617 & 0.05 \\
\hline & Within Groups & 0.4 & 14 & 0.025 & & \\
\hline & Total & 0.5 & 15 & & & \\
\hline \multirow[t]{3}{*}{$\mathrm{C} \%$} & Between Groups & 60.1 & 1 & 60.05 & 5.376 & 0.036 \\
\hline & Within Groups & 156.4 & 14 & 11.169 & & \\
\hline & Total & 216.4 & 15 & & & \\
\hline \multirow[t]{3}{*}{$\mathrm{C} / \mathrm{N}$} & Between Groups & 0.0 & 1 & 0.007 & 0.007 & 0.934 \\
\hline & Within Groups & 13.7 & 14 & 0.978 & & \\
\hline & Total & 13.7 & 15 & & & \\
\hline \multirow[t]{3}{*}{ OM \% } & Between Groups & 300.2 & 1 & 300.156 & 13.698 & 0.002 \\
\hline & Within Groups & 306.8 & 14 & 21.912 & & \\
\hline & Total & 606.9 & 15 & & & \\
\hline \multirow[t]{3}{*}{$\mathrm{Ca} \mathrm{kg} \mathrm{ha}^{-1}$} & Between Groups & 19091 & 1 & 19090.6 & 8.556 & 0.011 \\
\hline & Within Groups & 31236 & 14 & 2231.2 & & \\
\hline & Total & 50327 & 15 & & & \\
\hline \multirow[t]{3}{*}{$\mathrm{K} \mathrm{kg} \mathrm{ha}^{-1}$} & Between Groups & 6 & 1 & 5.734 & 0.032 & 0.86 \\
\hline & Within Groups & 2495 & 14 & 178.221 & & \\
\hline & Total & 2501 & 15 & & & \\
\hline \multirow[t]{3}{*}{ Mg kg ha ${ }^{-1}$} & Between Groups & 3 & 1 & 2.519 & 0.022 & 0.884 \\
\hline & Within Groups & 1609 & 14 & 114.898 & & \\
\hline & Total & 1611 & 15 & & & \\
\hline \multirow[t]{3}{*}{ P kg ha ${ }^{-1}$} & Between Groups & 48.419 & 1 & 48.419 & 0.869 & 0.367 \\
\hline & Within Groups & 779.861 & 14 & 55.704 & & \\
\hline & Total & 828.28 & 15 & & & \\
\hline
\end{tabular}


Table 11 One-way ANOVA for the treatment effect on total elemental pools in the mineral soil

\begin{tabular}{|c|c|c|c|c|c|c|}
\hline & & $\begin{array}{c}\text { Sum of } \\
\text { Squares }\end{array}$ & df & Mean Square & $\mathbf{F}$ & $\mathbf{p}$ \\
\hline \multirow[t]{3}{*}{$\mathrm{C} \mathrm{kg} \mathrm{ha}^{-1}$} & Between Groups & 53253552 & 1 & 53253552 & 2.839 & 0.114 \\
\hline & Within Groups & 262588391 & 14 & 18756314 & & \\
\hline & Total & 315841943 & 15 & & & \\
\hline \multirow[t]{3}{*}{$\mathrm{N} \mathrm{kg} \mathrm{ha}^{-1}$} & Between Groups & 243684 & 1 & 243684 & 3.977 & 0.066 \\
\hline & Within Groups & 857876 & 14 & 61277 & & \\
\hline & Total & 1101560 & 15 & & & \\
\hline \multirow[t]{3}{*}{ N\% } & Between Groups & 0.012 & 1 & 0.012 & 3.114 & 0.099 \\
\hline & Within Groups & 0.055 & 14 & 0.004 & & \\
\hline & Total & 0.067 & 15 & & & \\
\hline \multirow[t]{3}{*}{$\mathrm{C} \%$} & Between Groups & 2.576 & 1 & 2.576 & 2.134 & 0.166 \\
\hline & Within Groups & 16.897 & 14 & 1.207 & & \\
\hline & Total & 19.473 & 15 & & & \\
\hline \multirow[t]{3}{*}{$\mathrm{C} / \mathrm{N}$} & Between Groups & 0.456 & 1 & 0.456 & 0.233 & 0.636 \\
\hline & Within Groups & 27.319 & 14 & 1.951 & & \\
\hline & Total & 27.774 & 15 & & & \\
\hline \multirow[t]{3}{*}{ OM \% } & Between Groups & 22.801 & 1 & 22.801 & 3.138 & 0.098 \\
\hline & Within Groups & 101.709 & 14 & 7.265 & & \\
\hline & Total & 124.509 & 15 & & & \\
\hline \multirow[t]{3}{*}{$\mathrm{Ca} \mathrm{kg} \mathrm{ha}^{-1}$} & Between Groups & 35470.803 & 1 & 35470.803 & 2.96 & 0.107 \\
\hline & Within Groups & 167775.23 & 14 & 11983.945 & & \\
\hline & Total & 203246.033 & 15 & & & \\
\hline \multirow[t]{3}{*}{$\mathrm{K} \mathrm{kg} \mathrm{ha}^{-1}$} & Between Groups & 1262 & 1 & 1262 & 0.236 & 0.635 \\
\hline & Within Groups & 74839.858 & 14 & 5345.704 & & \\
\hline & Total & 76101.857 & 15 & & & \\
\hline \multirow[t]{3}{*}{$\mathrm{Mg} \mathrm{kg} \mathrm{ha}^{-1}$} & Between Groups & 2995.459 & 1 & 2995.459 & 0.083 & 0.777 \\
\hline & Within Groups & 503955.206 & 14 & 35996.8 & & \\
\hline & Total & 506950.665 & 15 & & & \\
\hline \multirow[t]{3}{*}{ P kg ha ${ }^{-1}$} & Between Groups & 5.78 & 1 & 5.78 & 0.018 & 0.895 \\
\hline & Within Groups & 4521.511 & 14 & 322.965 & & \\
\hline & Total & 4527.291 & 15 & & & \\
\hline
\end{tabular}


Table 12 One-way ANOVA for the treatment effect on exchangeable elemental pools in the organic layer

\begin{tabular}{|c|c|c|c|c|c|c|}
\hline & & $\begin{array}{c}\text { Sum of } \\
\text { Squares }\end{array}$ & df & Mean Square & $\mathbf{F}$ & $\mathbf{p}$ \\
\hline \multirow[t]{3}{*}{ Al kg ha ${ }^{-1}$} & Between Groups & 42.24 & 1 & 42.237 & 21.828 & 0.000 \\
\hline & Within Groups & 30.96 & 16 & 1.935 & & \\
\hline & Total & 73.20 & 17 & & & \\
\hline \multirow[t]{3}{*}{$\mathrm{Ca} \mathrm{kg} \mathrm{ha}^{-1}$} & Between Groups & 21647 & 1 & 21647.256 & 8.797 & 0.009 \\
\hline & Within Groups & 39370 & 16 & 2460.636 & & \\
\hline & Total & 61017 & 17 & & & \\
\hline \multirow[t]{3}{*}{ Fe kg ha ${ }^{-1}$} & Between Groups & 2.074 & 1 & 2.074 & 14.899 & 0.001 \\
\hline & Within Groups & 2.227 & 16 & 0.139 & & \\
\hline & Total & 4.301 & 17 & & & \\
\hline \multirow[t]{3}{*}{$\mathrm{K} \mathrm{kg} \mathrm{ha}^{-1}$} & Between Groups & 0.307 & 1 & 0.307 & 0.002 & 0.963 \\
\hline & Within Groups & 2165.9 & 16 & 135.366 & & \\
\hline & Total & 2166.2 & 17 & & & \\
\hline \multirow[t]{3}{*}{$\mathrm{Mg} \mathrm{kg} \mathrm{ha}^{-1}$} & Between Groups & 129.7 & 1 & 129.659 & 2.646 & 0.123 \\
\hline & Within Groups & 784.0 & 16 & 49.001 & & \\
\hline & Total & 913.7 & 17 & & & \\
\hline \multirow[t]{3}{*}{$\mathrm{Na} \mathrm{kg} \mathrm{ha}{ }^{-1}$} & Between Groups & 0.609 & 1 & 0.609 & 2.414 & 0.140 \\
\hline & Within Groups & 4.035 & 16 & 0.252 & & \\
\hline & Total & 4.643 & 17 & & & \\
\hline
\end{tabular}


Table 13 One-way ANOVA for the treatment effect on exchangeable elemental pools in the mineral soil

\begin{tabular}{|c|c|c|c|c|c|c|}
\hline & & $\begin{array}{c}\text { Sum of } \\
\text { Squares }\end{array}$ & df & Mean Square & $\mathbf{F}$ & $\mathbf{p}$ \\
\hline \multirow[t]{3}{*}{ Al kg ha ${ }^{-1}$} & Between Groups & 109.9 & 1 & 110 & 0.096 & 0.761 \\
\hline & Within Groups & 18366.8 & 16 & 1148 & & \\
\hline & Total & 18476.7 & 17 & & & \\
\hline \multirow[t]{3}{*}{$\mathrm{Ca} \mathrm{kg} \mathrm{ha}{ }^{-1}$} & Between Groups & 101455.6 & 1 & 101456 & 33.197 & 0.000 \\
\hline & Within Groups & 48898.9 & 16 & 3056 & & \\
\hline & Total & 150354.5 & 17 & & & \\
\hline \multirow[t]{3}{*}{ Fe kg ha ${ }^{-1}$} & Between Groups & 58.4 & 1 & 58 & 1.2 & 0.289 \\
\hline & Within Groups & 778.7 & 16 & 49 & & \\
\hline & Total & 837.2 & 17 & & & \\
\hline \multirow[t]{3}{*}{$\mathrm{K} \mathrm{kg} \mathrm{ha}^{-1}$} & Between Groups & 906.2 & 1 & 906 & 2.996 & 0.103 \\
\hline & Within Groups & 4839.9 & 16 & 302 & & \\
\hline & Total & 5746.2 & 17 & & & \\
\hline \multirow[t]{3}{*}{$\mathrm{Mg} \mathrm{kg} \mathrm{ha}^{-1}$} & Between Groups & 387.0 & 1 & 387 & 12.52 & 0.003 \\
\hline & Within Groups & 494.5 & 16 & 31 & & \\
\hline & Total & 881.5 & 17 & & & \\
\hline \multirow[t]{3}{*}{$\mathrm{Na} \mathrm{kg} \mathrm{ha}^{-1}$} & Between Groups & 0.302 & 1 & 0.302 & 0.078 & 0.784 \\
\hline & Within Groups & 61.908 & 16 & 3.869 & & \\
\hline & Total & 62.21 & 17 & & & \\
\hline
\end{tabular}


Table 14 One-way ANOVA for the treatment effect on cation rations in the organic layer

\begin{tabular}{llrrrrc}
\hline & Sum of Squares & df & Mean Square & F & p \\
\hline $\mathrm{Ca} / \mathrm{Al}$ & Between Groups & 3908.561 & 1 & 3908.561 & 32.303 & 0.000 \\
& Within Groups & 1935.958 & 16 & 120.997 & & \\
& Total & 5844.52 & 17 & & & \\
$\mathrm{Ca} / \mathrm{Mg}$ & Between Groups & 4.228 & 1 & 4.228 & 21.719 & 0.000 \\
& Within Groups & 3.114 & 16 & 0.195 & & \\
& Total & 7.342 & 17 & & & \\
$\mathrm{Mg} / \mathrm{Al}$ & Between Groups & 159.778 & 1 & 159.778 & 24.041 & 0.000 \\
& Within Groups & 106.337 & 16 & 6.646 & & \\
& Total & 266.115 & 17 & & & \\
\hline
\end{tabular}

Table 15 One-way ANOVA for the treatment effect on cation rations in the mineral soil.

\begin{tabular}{llrrrrr}
\hline & & Sum of Squares & df & Mean Square & F & p \\
\hline $\mathrm{Ca} / \mathrm{Al}$ & Between Groups & 1.63 & 1 & 1.63 & 10.973 & 0.004 \\
& Within Groups & 2.377 & 16 & 0.149 & & \\
& Total & 4.007 & 17 & & & \\
$\mathrm{Ca} / \mathrm{Mg}$ & Between Groups & 6.839 & 1 & 6.839 & 8.96 & 0.009 \\
& Within Groups & 12.213 & 16 & 0.763 & & \\
& Total & 19.051 & 17 & & & \\
$\mathrm{Mg} / \mathrm{Al} 1$ & Between Groups & 0.019 & 1 & 0.019 & 4.794 & 0.044 \\
& Within Groups & 0.064 & 16 & 0.004 & & \\
& Total & 0.083 & 17 & & & \\
\hline
\end{tabular}




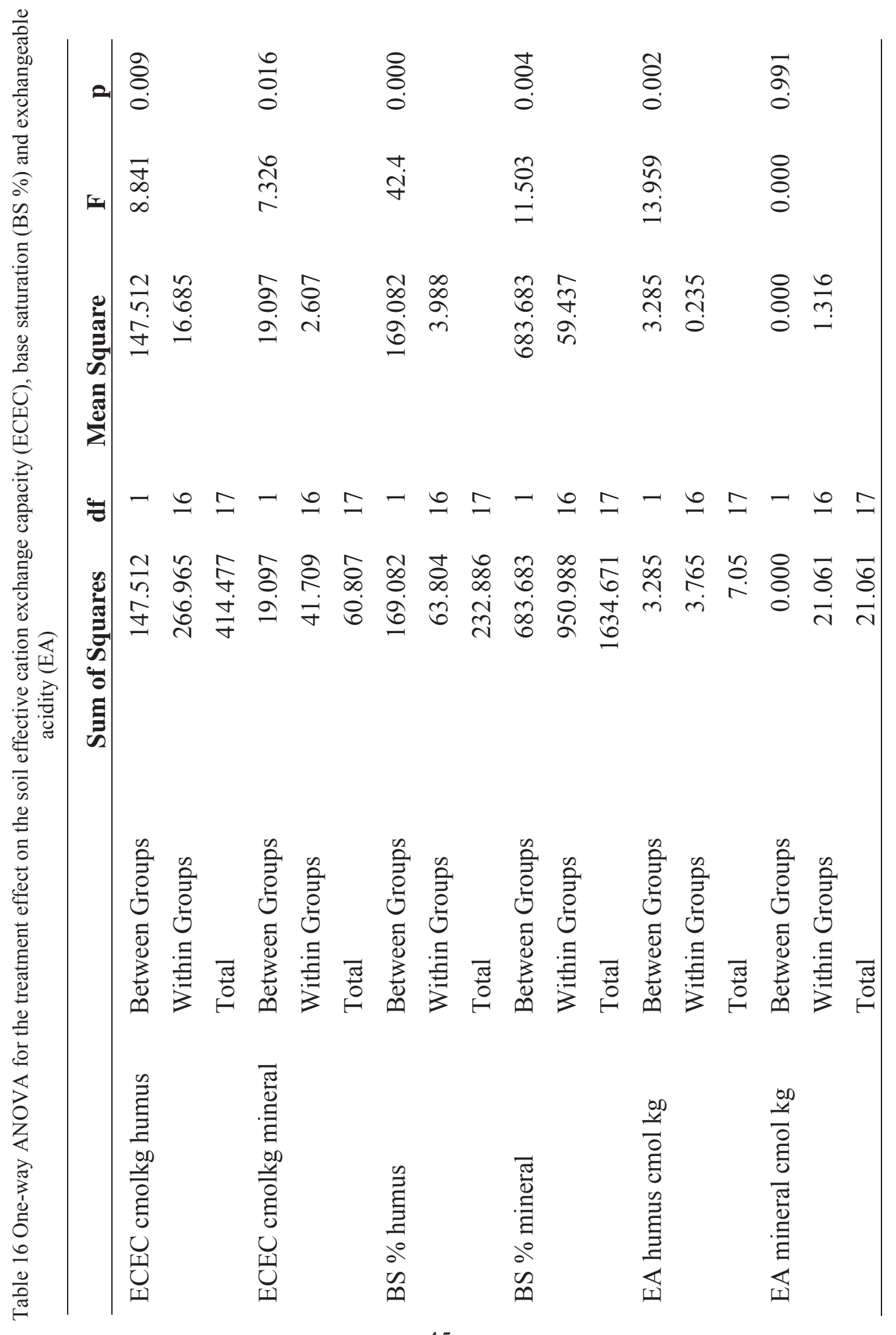




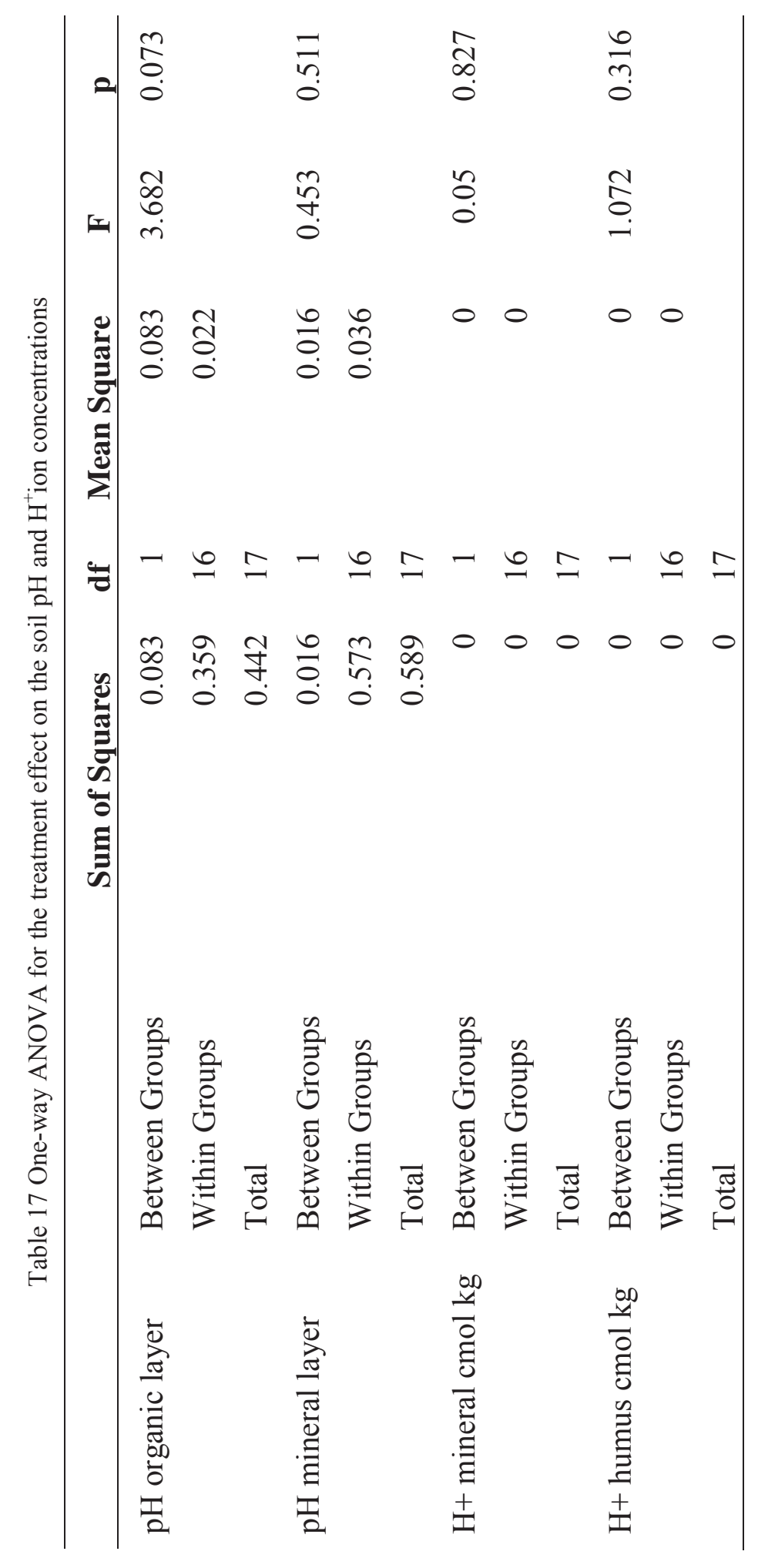




\section{Appendix II}

\section{Documentation for (Figure 4)}

\section{National Land Survey open data licence - version 1.0 - 1 May 2012}

\section{General information}

The National Land Survey of Finland (hereinafter the Licensor), as the holder of the immaterial rights to the data, has granted on the terms mentioned below the right to use a copy (hereinafter data or dataset(s)) of the data (or a part of it). The Licensee is a natural or legal person who makes use of the data covered by this licence. The Licensee accepts the terms of this licence by receiving the dataset(s) covered by the licence.

This Licence agreement does not create a co-operation or business relationship between the Licensee and the Licensor.

\section{Terms of the licence}

\subsection{Right of use}

This licence grants a worldwide, free of charge and irrevocable parallel right of use to open data. According to the terms of the licence, data received by the Licensee can be freely:

copied, distributed and published, modified and utilized commercially and noncommercially, inserted into other products and used as a part of a software application or service.

\subsection{Duties and responsibilities of the Licensee}

Through reasonable means suitable to the distribution medium or method which is used in conjunction with a product containing data or a service utilising data covered by this licence or while distributing data, the Licensee shall:

- mention the name of the Licensor, the name of the dataset(s) and the time when the National Land Survey has delivered the dataset(s) (e.g.: contains data from the National Land Survey of Finland Topographic Database 06/2012)

- provide a copy of this licence or a link to it, as well as

- require third parties to provide the same information when granting rights to copies of dataset(s) or products and services containing such data and remove the name of the Licensor from the product or service, if required to do so by the Licensor.

The terms of this licence do not allow the Licensee to state in conjunction with the use of dataset(s) that the Licensor supports or recommends such use. 


\subsection{Duties and responsibilities of the Licensor}

The Licensor shall ensure that the Licensor has the right to grant rights to the dataset(s) in accordance with this licence. The data has been licensed "as is" and the Licensor

shall not be held responsible for any errors or omissions in the data, disclaims any warranty for the validity or up to date status of the data and shall be free from liability for direct or consequential damages arising from the use of data provided by the Licensor, and is not obligated to ensure the continuous availability of the data, nor to announce in advance the interruption or cessation of availability, and the Licensor shall be free from liability for direct or consequential damages arising from any such interruption or cessation.

\section{Jurisdiction}

Finnish law shall apply to this licence.

\section{Changes to this licence}

The Licensor may at any time change the terms of the licence or apply a different licence to the data. The terms of this licence shall, however, still apply to such data that has been received prior to the change of the terms of the licence or the licence itself. 


\section{References}

Akselsson, C., Westling, O., Sverdrup, H. \& Gundersen, P. 2007. Nutrient and carbon budgets in forest soils as decision support in sustainable forest management. Forest Ecology and Management 238(1-3): 167-174.

Augusto, L., Ranger, J., Ponette, Q. \& Rapp, M. 2000. Relationships between forest tree species, stand production and stand nutrient amount. Annals of Forest Science 57(4): 313-324.

Bélanger, N., Paré, D. \& Yamasaki, H. 2003. The soil acid base status of boreal black spruce stands after whole-tree and stem-only harvesting. Canadian Journal of Forest Research 33(10): 1874-1879.

Björheden, R. 2006. Drivers behind the development of forest energy in Sweden. Biomass and Bioenergy 30(4): 289-295.

Bonan, G. B. \& Shugart, H. H. 1989. Environmental factors and ecological processes in boreal forests. Annual Reviews of Ecology and Systematics 201-28.

Brady, N. C. \& Weil, R. R. 2008. The nature and properties of soils. 14th edition. Prentice Hall, Harlow. 965 p.

Burger, J. A. 2002. Soil and long-term site productivity values. In: Richardson, J., Bjorheden, R., Hakkila, P., Lowe, A.T. \& Smith, C.T. (eds.). Bioenergy from sustainable forestry - guiding principles and practice. Kluwer Academic Publishers, London. p. 165189.

Cajander, A. K. 1949. Forest types and their significance. Acta Forestalia Fennica 56(5): $1-71$.

Domisch, T., Finér, L., Karsisto, M., Laiho, R. \& Laine, J. 1998. Relocation of carbon from decaying litter in drained peat soils. Soil Biology and Biochemistry 30(12): 15291536.

Doran, J. W. \& Jones, A. J. 1996. Methods for Assessing Soil Quality. Soil Science Society of America, Madison, WI. 410 p.

Egnell, G. 2011. Is the productivity decline in Norway spruce following whole-tree harvesting in the final felling in boreal Sweden permanent or temporary? Forest Ecology and Management 261(1): 148-153. 
- \& Leijon, B. 1999. Survival and growth of planted seedlings of Pinus sylvestris and Picea abies after different levels of biomass removal in clear-felling. Scandinavian Journal of Forest Research 14(4): 303-311.

Ericsson, K. 2004. Bioenergy policy and market development in Finland and Sweden. Energy Policy 32(15): 1707-1721.

European Commission. 2008. Proposal for a directive of the European parliament and of the council on the promotion of the use of energy from renewable sources. COM(2008) 19 final.

Fahey, T. J., Stevens, P. A., Hornung, M. \& Rowland, P. 1991. Decomposition and nutrient release from logging residue following conventional harvest of sitka spruce in North Wales. Forestry 64(3): 289-301.

Finér, L., Mannerkoski, H., Piirainen, S. \& Starr, M. 2003. Carbon and nitrogen pools in an old-growth, Norway spruce mixed forest in eastern Finland and changes associated with clear-cutting. Forest Ecology and Management 174(1-3): 51-63.

Giesler, R., Ilvesniemi, H., Nyberg, L., van Hees, P., Starr, M., Bishop, K. et al. 2000. Distribution and mobilization of Al, Fe and $\mathrm{Si}$ in three podzolic soil profiles in relation to the humus layer. Geoderma 94(2-4): 249-263.

Hakkila, P. 2006. Factors driving the development of forest energy in Finland. Biomass and Bioenergy 30(4): 281-288.

- \& Parikka, M. 2002. Fuel resources from the forest. In: Richardson, J., Bjorheden, R., Hakkila, P., Lowe, A.T. \& Smith, C.T. (eds.). Bioenergy from sustainable forestry guiding principles and practice. Kluwer Academic Publishers, The Netherlands. p. 19-48.

-, Nurmi J. \& Kalaja, H. 1998. Metsänuudistusalojen hakkuutähde energianlähteenä (Logging residue from regeneration cuttings as an energy source).

Metsäntutkimuslaitoksen tiedonantoja 684:1-68. (In Finnish)

Hallsby, G. \& Örlander, G. 2004. A comparison of mounding and inverting to establish Norway spruce on podzolic soils in Sweden. Forestry 77(2): 107.

Hazlett, P. W., Gordon, A. M., Voroney, R. P. \& Sibley, P. K. 2007. Impact of harvesting and logging slash on nitrogen and carbon dynamics in soils from upland spruce forests in northeastern Ontario. Soil Biology and Biochemistry 39(1): 43-57.

Helmisaari, H-S, Makkonen, K., Kellomäki, S., Valtonen, E. \& Mälkönen, E. 2002. 
Below- and above-ground biomass, production and nitrogen use in Scots pine stands in eastern Finland. Forest Ecology and Management 165(1-3): 317-326.

-, Kukkola, M., Luiro, J., Smolander, A., Saarsalmi, A. \& Tamminen P. 2009.

Hakkuutähteiden korjuu - muuttuuko typen saatavuus? Metsätieteen aikakauskirja (1): 57-62. (In Finnish)

- , Hanssen, K.H., Jacobson, S., Kukkola, M., Luiro, J., Saarsalmi, A., Tamminen, P. \& Tveite, B. 2011. Logging residue removal after thinning in Nordic boreal forests: Longterm impact on tree growth. Forest Ecology and Management 261(11): 1919-1927.

- , Finér, L., Lindroos, A., Luiro, J., Piirainen, S., Saarsalmi, A., Smolander, A. \& Tamminen, P. 2008. Energiapuun korjuu ja metsän ravinnetase (fuelwood extraction and stand nutrient status). In: Kuusinen, M., \& Ilvesniemi, H. (eds.). Energiapuun korjuun ympäristövaikutukset: Tutkimusraportti (an environmental assessment report on the effects of fuelwood harvest in finland). Metsäntutkimuslaitos, Helsinki. p. 18-29. (In Finnish)

Hope, G. D. 2007. Changes in soil properties, tree growth, and nutrition over a period of 10 years after stump removal and scarification on moderately coarse soils in interior British Columbia. Forest Ecology and Management 242(2-3): 625-635.

Hyvönen, R., Olsson, B. A., Lundkvist, H. \& Staaf, H. 2000. Decomposition and nutrient release from Picea abies (L.) Karst. and Pinus sylvestris L. logging residues. Forest Ecology and Management 126(2): 97-112.

IBM. 2012. SPSS Statistics package for Mac OS X. Version 20.

Jacobson, S., Kukkola, M., Mälkönen, E. \& Tveite, B. 2000. Impact of whole-tree harvesting and compensatory fertilization on growth of coniferous thinning stands. Forest Ecology and Management 129(1-3): 41-51.

Johansson, M. 1994. Decomposition rates of Scots pine needle litter related to site properties, litter quality, and climate. Canadian Journal of Forest Research 24(9): 17711781.

Johnson, C. E., Johnson, A. H., Huntington, T. G. \& Siccama, T. G. 1991a. Whole-Tree Clear-Cutting Effects on Exchangeable Cations and Soil Acidity. Soil Science Society of America Journal 55(2): 502-508.

-, Johnson, A. H., Huntington, T. G. \& Siccama, T. G. 1991b. Whole-Tree Clear-Cutting Effects on Soil Horizons and Organic-Matter Pools. Soil Science Society of America Journal 55(2): 497-502. 
Johnson, D. W. \& Curtis, P. S. 2001. Effects of forest management on soil carbon and nitrogen storage: meta analysis. Forest Ecology and Management 140(2-3): 227-238.

- \& Curtis, P.S. 2002. Effects of forest management on soil carbon: results of some longterm resampling studies. Environmental Pollution 116:201-208.

Jurgensen, M. F., Harvey, A. E., Graham, R. T., Page-Dumroese, D. S., Tonn, J. R., Larsen, M. J. \& Jain, T. B. 1997. Impacts of timber harvesting on soil organic matter, nitrogen, productivity, and health of inland Northwest forests. Forest Science 43(2): 234 251.

Kimmins, J. P. 1977. Evaluation of the consequences for future tree productivity of the loss of nutrients in whole-tree harvest. Forest Ecology and Management 1:169-183.

Laitila, J., Asikainen, A. \& Anttila, P. 2008. Energiapuuvarat (potential fuelwood stocks in Finland). In: Kuusinen, M., \& Ilvesniemi, H. (eds.). Energiapuun korjuun ympäristövaikutukset: Tutkimusraportti (an environmental assessment report on the effects of fuelwood harvest in Finland). Metsäntutkimuslaitos, Helsinki. p. 6-11. (In Finnish)

Likens, G. E. \& Bormann, F. H. 1995. Biogeochemistry of a Forested Ecosystem. 2nd edition. Springer, New York. 159 p.

- , Bormann, F.H., Johnson, N.M., Fisher, D.W. \& Pierce, R.S. 1970. Effects of Forest Cutting and Herbicide Treatment on Nutrient Budgets in the Hubbard Brook WatershedEcosystem. Ecological Monographs 40(1): 23-47.

Luiro, J., Kukkola, M., Saarsalmi, A., Tamminen, P. \& Helmisaari, H-S. 2010. Logging residue removal after thinning in boreal forests: long-term impact on the nutrient status of Norway spruce and Scots pine needles. Tree physiology 30(1): 78-88.

Mahendrappa, M. K., Foster, N. W., Weetman, G. F. \& Krause, H. H. 1986. Nutrient cycling and availability in forest soils. Canadian Journal of Soil Science 66(4): 547-572.

Michéli, E., Schad, P. \& Spaargaren, O. 2006. World Reference Base for Soils. ISSS, ISRIC, FAO, Rome. 145 p.

Moroni, M. T., Carter, P. Q., Strickland, D. W., Makeschin, F., Parkinson, D. \& Kahnt, L. 2007. Effect of forest harvesting and slash piling on microbial biomass and respiration in Newfoundland boreal forests. Canadian Journal of Soil Science 87(4): 455-458.

Mälkönen, E. 1976. Effect of whole-tree harvesting on soil fertility. Silva Fennica 10(3): $157-164$. 
National Land Survey of Finland. 2012. General Map Database, accessed 05/2012.

Licence available at:

http://www.maanmittauslaitos.fi/en/NLS open_data licence version1_20120501. 2012 (Cited 08/10/2012).

Nurmi, J. 2007. Recovery of logging residues for energy from spruce (Pices abies) dominated stands. Biomass and Bioenergy 31(6): 375-380.

Nykvist, N. \& Rosen, K. 1985. Effect of clear-felling and slash removal on the acidity of Northern coniferous soils. Forest Ecology and Management 11(3): 157-169.

Olsson, B., Lundkvist, H. \& Staaf, H. 2000. Nutrient status in needles of Norway spruce and Scots pine following harvesting of logging residues. Plant and Soil 223(1): 163-175.

Olsson, B. A. 1999. Effects of biomass removal in thinnings and compensatory fertilization on exchangeable base cation pools in acid forest soils. Forest Ecology and Management 122(1-2): 29-39.

Olsson, B. A. \& Staaf, H. 1995. Influence of Harvesting Intensity of Logging Residues on Ground Vegetation in Coniferous Forests. Journal of Applied Ecology 32:640-654.

-, Bengtsson, J. \& Lundkvist, H. 1996a. Effects of different forest harvest intensities on the pools of exchangeable cations in coniferous forest soils. Forest Ecology and Management 84(1-3): 135-147.

- , Staaf, H., Lundkvist, H., Bengtsson, J. \& Rosen, J. 1996b. Carbon and nitrogen in coniferous forest soils after clear-felling and harvests of different intensity. Forest Ecology and Management 82(1-3): 19-32.

Palviainen, M. 2005. Logging residues and ground vegetation in nutrient dynamics of a clear-cut boreal forest. Ph.D. University of Joensuu, $39 \mathrm{p}$.

- \& Finér, L. 2012. Estimation of nutrient removals in stem-only and whole-tree harvesting of Scots pine, Norway spruce, and birch stands with generalized nutrient equations. European Journal of Forest Research 131(4): 945-964.

-, Starr, M. \& Westman, C.J. 2012. The effect of site fertility and climate on current weathering in Finnish forest soils: Results of a 10-16 year study using buried crushed test-rock material. Geoderma 183-18458-66.

-, Finér, L., Kurka, A. M., Mannerkoski, H., Piirainen, S. \& Starr, M. 2004a. Release of potassium, calcium, iron and aluminium from Norway spruce, Scots pine and silver birch logging residues. Plant \& Soil 259(1): 123-136. 
- , Finér, L., Kurka, A. M., Mannerkoski, H., Piirainen, S. \& Starr, M. 2005. Changes in the above- and below-ground biomass and nutrient pools of ground vegetation after clearcutting of a mixed boreal forest. Plant and Soil 275(1-2): 157-167.

- , Finér, L., Kurka, A.M., Mannerkoski, H., Piirainen, S. \& Starr, M. 2004b.

Decomposition and nutrient release from logging residues after clear-cutting of mixed boreal forest. Plant and Soil 263(1-2): 53-67.

Paré, D., Rochon, P. \& Brais, S. 2002. Assessing the geochemical balance of managed boreal forests. Ecological Indicators 1(4): 293-311.

Peltola, S., Kilpeläinen, H. \& Asikainen, A. 2011. Recovery rates of logging residue harvesting in Norway spruce (Picea abies (L.) Karsten) dominated stands. Biomass \& Bioenergy 35(4): 1545-1551.

Piirainen, S. 2002. Nutrient fluxes through a boreal coniferous forest and the effects of clear-cutting. Ph.D. Finnish Forest Research Institute, Research Papers 859, Joensuu. 50 p.

-, Finér, L., Mannerkoski, H. \& Starr, M. 2007. Carbon, nitrogen and phosphorus leaching after site preparation at a boreal forest clear-cut area. Forest Ecology and Management 243(1): 10-18.

- , Finér, L., Mannerkoski, H. \& Starr, M. 2004. Effects of forest clear-cutting on the sulphur, phosphorus and base cations fluxes through podzolic soil horizons. Biogeochemistry 69(3): 405-424.

-, Finér, L., Mannerkoski, H. \& Starr, M. 2002. Effects of forest clear-cutting on the carbon and nitrogen fluxes through podzolic soil horizons. Plant and Soil 239(2): 301311.

Prescott, C. E. 2002. The influence of the forest canopy on nutrient cycling. Tree physiology 22(15-16): 1193-1200.

-2000 . Humus in northern forests: friend or foe? Forest Ecology and Management 133(1-2): 23-36.

Proe, M. F. \& Dutch, J. 1994. Impact of Whole-Tree Harvesting on Second-Rotation Growth of Sitka Spruce: the First 10 Years. Forest Ecology and Management 66(1): 3954.

Raulund-Rasmussen, K., Stupak, I., Clarke, N., Callesen, I., Helmisaari, H-S., Karltun, E. $\&$ Varnagiryte, I. 2008. Effects of very intensive forest biomass harvesting on short and long-term site productivity. In: Röser, D., Asikainen, A., Raulund-Rasmussen, K. \& 
Stupak, I. (eds.). Sustainable use of forest biomass for energy. managing forest ecosystems, vol. 12. Springer, Dordrecht. p. 29-78.

Repola, J. 2009. Biomass equations for Scots pine and Norway spruce in Finland. Silva Fennica Monographs 43(4): 625-647.

Rosen, K. \& Lundmark-Thelin, A. 1987. Increased nitrogen leaching under piles of slasha consequence of modern forest harvesting techniques. Scandinavian Journal of Forest Research 2(1-4): 21-29.

Rosenberg, O. \& Jacobson, S. 2004. Effects of repeated slash removal in thinned stands on soil chemistry and understorey vegetation. Silva Fennica 38(2): 133-142.

Ruoho-Airola, T., Alaviippola, B., Salminen, K. \& Varjoranta, R. 2003. An Investigation of base cation deposition in Finland. Boreal Environment Research 8(2): 83-95.

Saarsalmi, A., Tamminen, P., Kukkola, M. \& Hautajarvi, R. 2010. Whole-tree harvesting at clear-felling: Impact on soil chemistry, needle nutrient concentrations and growth of Scots pine. Scandinavian Journal of Forest Research 25(2): 148-156.

Saksa, T., Tervo, L. \& Levula, T. 2002. Hakkuutähde ja metsän uudistaminen. Hakkuutähteen korjuun vaikutukset metsänuudistamiseen tutkimushankkeen loppuraportti (Logging residues and forest regeneration). Metsäntutkimuslaitoksen tiedonantoja 8511-41. (In Finnish)

Smolander, A., Levula, T. \& Kitunen, V. 2008. Response of litter decomposition and soil $\mathrm{C}$ and $\mathrm{N}$ transformations in a Norway spruce thinning stand to removal of logging residue. Forest Ecology and Management 256(5): 1080-1086.

- , Kitunen, V., Tamminen, P., \& Kukkola, M. 2010. Removal of logging residue in Norway spruce thinning stands: Long-term changes in organic layer properties. Soil Biology and Biochemistry 42(8): 1222-1228.

- , Kitunen, V., Paavolainen, L. \& Mälkönen, E. 1996. Decomposition of Norway spruce and Scots pine needles: Effects of liming. Plant and Soil 179(1): 1-7.

Starr, M., Lindroos, A., Tarvainen, T. \& Tanskanen, H. 1998. Weathering rates in the Hietajärvi Integrated Monitoring catchment. Boreal Environment Research 3:275-285.

Stupak, I., Asikainen, A., Jonsell, M., Karltun, E., Lunnan, A., Mizaraite, D. et al. 2007. Sustainable utilisation of forest biomass for energy-Possibilities and problems: Policy, legislation, certification, and recommendations and guidelines in the Nordic, Baltic, and other European countries. Biomass and Bioenergy 31(10): 666-684. 
Sverdrup, H. \& Rosen, K. 1998. Long-term base cation mass balances for Swedish forests and the concept of sustainability. Forest Ecology and Management 110(1-3): $221-236$.

Tamminen, P. 2009. Suomen metsämaiden maannokset. Metsätieteen aikakausikirja 1:74-78. (In Finnish)

- \& Starr, M. 1994. Bulk density of forested mineral soils. Silva Fennica 28(1): 53-60.

-, Saarsalmi, A., Smolander, A., Kukkola, M. \& Helmisaari H-S. 2012. Effects of logging residue harvest in thinnings on amounts of soil carbon and nutrients in Scots pine and Norway spruce stands. Forest Ecology and Management 263:31-38.

Thelin, G., Rosengren, U., Callesen, I. \& Ingerslev, M. 2002. The nutrient status of Norway spruce in pure and in mixed-species stands. Forest Ecology and Management 160(1-3): 115-125.

Thiffault, E., Hannam, K. D., Paré, D., Titus, B. D., Hazlett, P. W., Maynard, D. G. \& Brais, S. 2011. Effects of forest biomass harvesting on soil productivity in boreal and temperate forests-a review. Environmental Reviews 19:278-309.

Thiffault, E., Pare, D., Belanger, N., Munson, A. \& Marquis, F. 2006. Harvesting Intensity at Clear-Felling in the Boreal Forest: Impact on Soil and Foliar Nutrient Status. Soil Science Society of America Journal 70(2): 691-701.

Ukonmaanaho, L., Merilä, P., Njod, P. \& Nieminen, T. M. 2008. Litterfall production and nutrient return to the forest floor in Scots pine and Norway spruce stands in Finland. Boreal Environment Research 13:67-91.

Vanguelova, E., Pitman, R., Luiro, J. \& Helmisaari, H-S. 2010. Long term effects of whole tree harvesting on soil carbon and nutrient sustainability in the UK. Biogeochemistry 101(1-3): 43-59.

Viro, P. 1952. Kivisyyden määrittämisestä. On the determination of stoniness. Communicationes Instituti Forestalis Fenniae 40(3): 1-23. (In Finnish)

Wall, A. 2008. Effect of removal of logging residue on nutrient leaching and nutrient pools in the soil after clearcutting in a Norway spruce stand. Forest Ecology and Management 256(6): 1372-1383.

- \& Hytönen, J. 2011. The long-term effects of logging residue removal on forest floor nutrient capital, foliar chemistry and growth of a Norway spruce stand. Biomass and Bioenergy 35(8): 3328-3334. 
Walmsley, J. D., Jones, D. L., Reynolds, B., Price, M. H. \& Healey, J. R. 2009. Whole tree harvesting can reduce second rotation forest productivity. Forest Ecology and Management 257(3): 1104-1111.

Worrell, R. \& Hampson, A. 1997. The influence of some forest operations on the sustainable management of forest soils - A review. Forestry 70(1): 61-85.

Ylitalo, E. 2011. Finnish Statistical Yearbook of Forestry. Finnish Forest Research Institute, Vammalan Kirjapaino, Sastamala. 469 p. 